\author{
PAWEE ZAJĄC \\ https://orcid.org/0000-0003-1764-9976 \\ Uniwersytet im. Adama Mickiewicza w Poznaniu \\ Wydział Teologiczny
}

\title{
WARSZAWSKA MISJA NUNCJUSZA ANGELA DURINIEGO OD JEJ INAUGURACJI DO KOŃCA PIERWSZEGO ROKU KONFEDERACJI BARSKIEJ (LIPIEC 1767 ～LUTY 1769)
}

\begin{abstract}
Abstrakt: Angelo Maria Durini był nuncjuszem w Rzeczypospolitej w latach 17671772. Historycy nieraz zastanawiali się, czy tylko reprezentował stanowisko papieża, czy też wychodził poza jego instrukcje. Postawa Duriniego dyplomaty oraz stosunki z opozycją antykrólewską zdają się sugerować nie tyle przekraczanie kompetencji, co jednostronne podejście do papieskich dyrektyw, którym nieobca była koncepcja kompromisu.
\end{abstract}

Słowa kluczowe: nuncjatura, sejm radomski, konfederacja barska, Angelo Maria Durini, Stanisław August Poniatowski, dyplomacja.
Abstract: Angelo Maria Durini was papal nuncio in the Polish-Lithuanian Commonwealth in 1767-1772. Historians have asked more than once whether he only represented the position of the pope or whether he exceeded his instructions. The attitude of the diplomat Durini and his relations with the anti-royal opposition seem to suggest not so much overstepping his authority as a one-sided approach to papal directives that were quite familiar with the concept of compromise.

Keywords: nunciature, Radom Sejm, Confederation of Bar, Angelo Maria Durini, Stanisław August Poniatowski, diplomacy.

Podjęcie tematu dyplomacji papieskiej w kontekście konfederacji barskiej - przy dostępności wielu obszernych i wszechstronnych studiów poświęconych Barowi ${ }^{1}$ - domaga się precyzyjnego uzasadnienia. Podstawa

${ }^{1}$ W. Konopczyński, Konfederacja barska, t. 1-2, Warszawa 1991 (wyd. 1: 1936-1938); J. Michalski, Schyłek konfederacji barskiej, Wrocław 1970; W. Kęder, Stolica Apostolska wobec Rzeczypospolitej w okresie konfederacji barskiej 1767-1773, Opole 2006; Konfederacja barska. 
źródłowa wykorzystana poniżej była wielokrotnie analizowana - stanowią ją instrukcje dla nuncjusza w Rzeczypospolitej, abpa Angela Marii Duriniego, i jego depesze adresowane do sekretarza stanu Stolicy Apostolskiej, kard. Ludovica Marii Torrigianiego. W kilku zaledwie miejscach wypadnie sięgnąć także do innych fragmentów gromadzonej w Rzymie korespondencji dyplomatycznej, które pozwolą m.in. na dostrzeżenie istotnej różnicy w ocenie spraw polskich przez nuncjusza Duriniego i jego poprzednika, abpa Antonia Eugenia Viscontiego; ten ostatni latem 1767 r. objął funkcję nuncjusza apostolskiego w Wiedniu. Granice chronologiczne artykułu wyznacza początek misji dyplomatycznej abpa Duriniego w Warszawie (lipiec 1767) i śmierć papieża Klemensa XIII, 2 lutego 1769 r.; jej konsekwencją była także zmiana na stanowisku sekretarza stanu.

Kilka pokoleń historyków, począwszy od Augustina Theinera, korzystało z tej korespondencji, analizując stosunek Stolicy Apostolskiej do Rzeczypospolitej w latach $1767-1772^{2}$. Ich konkluzje nierzadko były przeciwstawne, a polemikę ogniskowano najczęściej wokół odmiennych interpretacji postawy nuncjusza Duriniego jako reprezentanta papieża. Według włoskiego historyka Domenica Caccama, to polski historyk Maciej Loret jako pierwszy dostrzegł rozbieżność między instrukcjami sekretariatu stanu w okresie konfederacji barskiej a działaniami Duriniego ${ }^{3}$. Studium Caccama miało na celu wykazanie, że „prawdziwe stanowisko papiestwa wobec Rzeczypospolitej w tych latach można poznać dzięki dokumentom zredagowanym w Rzymie, a nie na podstawie oficjalnej korespondencji Duriniego, który wypełniał instrukcje Kurii, mówiąc delikatnie, ze skrajną dowolnością [„,con estrema libertà”]”4. Caccamo jednocześnie wskazał na odmienne interpretacje postawy Duriniego, podtrzymane w pierwszym tomie Sacrum Poloniae Millenium. Autor tej publikacji dostrzegał w abpie Durinim gorliwego dyplomatę, którego poczynania Stolica Apostolska w pełni aprobowała ${ }^{5}$.

Jej konteksty i tradycje, red. A. Buchmann, A. Danilczyk, Warszawa 2010. Jerzy Michalski już w 1970 r. napisał, iż „czasy konfederacji barskiej można uznać, obok insurekcji kościuszkowskiej, za najdokładniej zbadany okres panowania Stanisława Augusta", J. Michalski, op. cit., s. 3.

${ }^{2}$ Vetera monumenta Poloniae et Lithuaniae gentiumque finitimarum historiam illustrantia, wyd. A. Theiner, t. 4, cz. 2, Romae 1864 (dalej: Theiner). O głównych liniach historiografii tego okresu historii Rzeczypospolitej w kontekście polityki Stolicy Apostolskiej zob. D. Caccamo, Il nunzio A.M. Durini (1767-72) e la prima spartizione di Polonia, w: Italia Venezia e Polonia tra illuminismo e romanticismo, wyd. V. Branca, Firenze 1973, s. 37-68 (zwł. s. 37-41).

${ }^{3}$ D. Caccamo, op. cit., s. 39.

${ }^{4}$ Ibidem, s. 41.

${ }^{5}$ E. Duda, Le Saint-Siège devant les événements politiques de Pologne à la veille de son premier partage, „Sacrum Poloniae Millenium” 1, 1954, s. 139-207. Artykuł Dudy kończył się 
Polemika wynikła z przeciwstawnych punktów widzenia odżyła w pierwszych latach XXI w. Wojciech Kęder w licznych publikacjach podkreślał, iż „Durini kierował się otrzymaną instrukcją i wytycznymi napły-

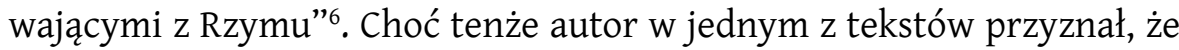
nuncjusz był „impulsywny i często przekraczający zwyczajowo zakreślone dla dyplomaty granice" , a na innym miejscu dodał, że „błąd arcybiskupa Duriniego [--] polegał na tym, iż nieostrożnie przekraczając swoje uprawnienia dyplomaty zbyt otwarcie okazywał swoją sympatię wpierw wobec opozycji antykrólewskiej, a później ruchu barskiego" ${ }^{8}$, to jednak w recenzji książki Magdaleny Wrany wrócił do pierwotnego poglądu:

opinie Autorki o tym - pisał - iż rzekomo nuncjusz Durini nie realizował dyrektyw Stolicy Apostolskiej, nie znajdują potwierdzenia w źródłach. Wręcz przeciwnie: [--] pomimo że jeszcze w 1767 r. Repnin wraz z królem czynią starania o odwołanie nuncjusza z Warszawy, to Durini wyjeżdża dopiero pięć lat później [--]. A zatem Klemens XIII i Klemens XIV przez cztery lata sabotowali żądania Stanisława Augusta, utrzymując w Warszawie swojego przedstawiciela mającego tak złe relacje z monarchą. Dlaczego to robili? Bo arcybiskup Durini wszelkimi siłami, jak potrafił, wypełniał jako papieski wysłannik ich zalecenia9.

na okresie sejmu radomskiego. Autor podkreślił, że stanowcza obrona praw katolicyzmu w tym czasie spotkała się z pełną aprobatą sekretarza stanu, ibidem, s. 180.

${ }^{6}$ W. Kęder, Stolica Apostolska, s. 303. Bibliografia autora uwzględniająca wiele tekstów dotyczących nuncjusza Duriniego oraz okresu konfederacji barskiej zob. http:// upjp2.edu.pl/edumod/pracownik/459/Wojciech+K\%C4\%99der (dostęp: XII 2018).

7 W. Kęder, Kryzys wokót sprawy dysydenckiej a sprawa suwerenności Rzeczypospolitej w latach 1764-1767 w świetle dokumentów papieskiego sekretariatu stanu, w: Rzeczpospolita wielu wyznań, red. A. Kaźmierczyk i in., Kraków 2004, s. 367 (cały artykuł s. 365-374).

${ }^{8}$ W. Kęder, Stolica Apostolska, s. 275, por. s. 303: „Jednocześnie jest pewnym, iż kierownicy dyplomacji papieskiej z niepokojem patrzyli na zbyt jawne okazywanie przez arcybiskupa Duriniego sympatii ruchowi barskiemu, gdzie nuncjusz z pewnością niejednokrotnie przekroczył granice zwyczajowo zakreślone dla dyplomaty akredytowanego przy obcym dworze i reprezentującego interesy swoich przełożonych".

9 W. Kęder, rec.: Magdalena Wrana, Angelo Maria Durini. Poeta i polityk w purpurze. Zarys działalności literackiej, kulturalnej i politycznej nuncjusza w Polsce, Kraków 2013, „Studia Sandomierskie” 21, 2014, s. 324. Na innym miejscu Kęder pisał: „Instrukcje, jakie otrzymał przybywający do Polski nuncjusz Durini w sytuacji, jaka istniała w kraju latem 1767 r., nie dawały mu żadnego pola manewru. Musiał wystąpić w obronie interesów religii katolickiej, narażając się na gniew ambasadora Repnina, a tym samym również [- - ] Stanisława Augusta [- - ]. I to właśnie ten konflikt dotyczący spraw o zasadniczym znaczeniu, a nie przekroczenie uprawnień dyplomaty i opowiedzenie się po stronie opozycji w okresie konfederacji barskiej, o co oskarżali Duriniego niejednokrotnie historycy zajmujący się tą problematyką, zadecydował o tym, że drogi monarchy i nuncjusza rozeszły się, a wzajemna wrogość trwała aż do odwołania Duriniego z Polski w 1772 r.", 
Recenzowana autorka, oceniając realizację dyrektyw papieskich przez nuncjusza Duriniego, przyjęła punkt widzenia Loreta i Caccama ${ }^{10}$. Był to jednak wątek poboczny jej publikacji poświęconej artystycznym pasjom nuncjusza.

Przeciwstawne poglądy w historiografii prowokują do pytań i zachęcają do refleksji nad działalnością warszawskiego nuncjusza z lat 17671772. Dalsze wywody dotyczyć będą treści trzech rodzajów źródeł: Instrukcji sekretariatu stanu Stolicy Apostolskiej wręczonej Duriniemu na początku misji dyplomatycznej, jego depesz w początkowym okresie działalności w Warszawie oraz tychże depesz w pierwszym roku konfederacji barskiej. Priorytet przyznany relacjom nuncjusza ma na celu wnikliwe spojrzenie na jego punkt widzenia w ocenie osób i wydarzeń ${ }^{11}$.

Co do raportów Duriniego, trzeba zaznaczyć, że historycy korzystali $\mathrm{z}$ nich często nie $\mathrm{w}$ oryginale, lecz za pośrednictwem edycji Theinera. Tymczasem już w XIX w. Augusto de Benedetti zauważył, że wydawnictwo to zamieściło jedynie wybór relacji nuncjuszy ${ }^{12}$. Ograniczenie się wyłącznie do edycji Theinera zaważyło na niepełności ujęć tych badaczy, którzy nie sięgnęli do relacji nuncjuszy spoza niej ${ }^{13}$. Z tego względu, korzystając z watykańskich oryginałów, będę zaznaczał obecność lub brak pewnych fragmentów depesz w edycji Theinera.

\section{Kilka uwag o Instrukcji dla nuncjusza Duriniego z 26 czerwca 1767 roku}

Oceny postawy nuncjusza Duriniego wobec problemów Rzeczypospolitej zależą często od odpowiedzi na pytanie, czy realizował on wiernie

W. Kęder, Od Viscontiego do Garampiego - nuncjatura warszawska w pierwszym okresie panowania króla Stanisława Augusta Poniatowskiego, w: Nuncjatura Apostolska w Rzeczypospolitej, red. T. Chynczewska-Hennel, K. Wiszowata-Walczak, Białystok 2012, s. 371 (cały artykuł s. 361-373). Por. M. Wrana, Angelo Maria Durini. Poeta i polityk w purpurze. Zarys działalności literackiej, kulturalnej i politycznej nuncjusza w Polsce (1767-1772), Kraków 2013.

10 Zob. np. M. Wrana, op. cit., s. 30, 66, 68.

${ }^{11}$ Nie chodzi tu więc o pisanie na nowo historii relacji Stolicy Apostolskiej i Rzeczypospolitej - takie ujęcie domagałoby się wykorzystania szerszej podstawy źródłowej, o czym wspomniał już Domenico Caccamo, op. cit., s. 38, krytykując Theinera za wyłączną niemal koncentrację na depeszach nuncjusza. Zgodnie z sugestią Caccama poświęcę nieco miejsca na refleksję nad Instrukcją sekretariatu stanu dla abpa Duriniego.

12 F.A. De Benedetti, La diplomazia pontificia et la prima spartizione della Polonia, Pistoia 1896, s. 11 nn. Wbrew temu, co utrzymuje Caccamo (op. cit., s. 41), że Theiner przekazał „istotne fragmenty” depesz, zatem nie warto się już nimi zajmować, zdefiniowanie tego, co istotne w tych depeszach, jest kwestią wysoce dyskusyjną.

13 Dotyczy to np. wspomnianego wyżej artykułu Etienne’a Dudy. 
dyrektywy papieskie, czy też wykazywał się nieuprawnioną inicjatywą osobistą. Część historyków podkreśla, iż wytyczne z Watykanu nakazywały nuncjuszowi starannie rozróżniać sferę ściśle polityczną od religijnej/duchowej i w trosce o sprawy Kościoła katolickiego w Rzeczypospolitej zachować neutralność polityczną ${ }^{14}$. Inni akcentują nadrzędność papieskiego imperatywu podjęcia wszelkich działań w obronie prerogatyw katolicyzmu jako wyznania panującego, co wykluczało taką ścisłą neutralnośćc ${ }^{15}$. Źródłem przywoływanym w tej kwestii bywa właśnie Instrukcja sekretariatu stanu wręczona nuncjuszowi Duriniemu na początku jego misji, nakazująca stanowczy opór przeciw pretensjom dysydentów, a w pewnym miejscu sugerująca nawet moźliwość zerwania sejmu lub „inną podobnie fatalną konsekwencję, którą niech Bóg trzyma $\mathrm{z}$ dala" ${ }^{16}$. W odniesieniu do nakazu ścisłej neutralności politycznej przywołuje się depesze późniejsze od cytowanej Instrukcji, otrzymywane przez nuncjusza już po zawiązaniu konfederacji barskiej. Na przykład 28 maja 1768 r. kard. Torrigiani pisał do abpa Duriniego:

Po otrzymaniu od Waszej Ekscelencji [dalej: WE] w depeszy z 4 maja kolejnej relacji o losach nowej konfederacji oraz widząc, że dwór [warszawski] z pewnością zaczyna żywić coraz więcej obaw, Ojciec Święty utwierdza się we wcześniejszym przekonaniu co do postawy, jaką WE powinien przyjąć, to znaczy, aby w tak krytycznych okolicznościach podejmując jakiekolwiek kroki lub wypowiadając się, [WE czynił to] z taką ostrożnością i roztropnością, żeby nie sprowokować podejrzeń żadnej ze stron i w ten sposób być zawsze w stanie wspomóc religię w najlepszy możliwy sposób. Przede wszystkim proszę dołożyć starań, aby król zawiesił realizację postanowień

14 D. Caccamo, op. cit., s. 41-42. Odwołuje się do niego M. Wrana, op. cit., s. 48-49.

15 W. Kęder, Stolica Apostolska, s. 201, 270, 281, 303.

16 „Tutti questi sono punti di tale gelosia e importanza che non possono ammettere dissimulazione, pazienza o tolleranza veruna; ma per tutti e singoli essi dovrà Mons. Nunzio fare le opposizioni più vigorose, parlare, agire, adoperarsi e tenere ben fermi e costanti vescovi e tutti i più zelanti della Nazione, acciò con ogni forza resistano a qualunque contraria intrapresa, quand'anche ne potesse per ciò seguire rottura della Dieta o qualunque altra simile funesta conseguenza, che Iddio tenga lontana”, „Istruzione per Mons. Angelo Maria Durini Arcivescovo di Ancira destinato nunzio apostolico in Polonia" (dalej: Istruzione), [26 VI 1767], Archivio Segreto Vaticano (dalej: ASV), Segreteria dello Stato (dalej: Segr. Stato Polonia) 238, k. 128v. (całość k. 125-144v.). Edycja w: Acta Nuntiaturae Polonae, t. 52, Angelus Maria Durini (1767-1772), cz. 1: 12 IV 1766 - 20 IV 1768, wyd. W. Kęder, Cracoviae 2016 (dalej: ANP 52/1), N. 15. Por. W. Kęder, Stolica Apostolska, s. 202. Z uwagi na powtarzające się usterki w publikowanych tekstach cytuję bezpośrednio źródła watykańskie, dodając odniesienia do ich ewentualnych edycji. Rozbieżności w transkrypcji zostaną w niektórych przypadkach zasygnalizowane. 
ostatniego sejmu, co przy obecnym wzburzeniu narodu może także ubezpieczy go przed gniewem carycy ${ }^{17}$.

Wbrew wrażeniu, które może się zrodzić z zestawienia cytowanych wyżej źródeł rzymskich powstałych w odstępie roku, nie trzeba było czekać do pierwszych miesięcy konfederacji barskiej, by ze Stolicy Apostolskiej popłynął głos sugerujący nuncjuszowi ostrożność w poczynaniach w Rzeczypospolitej. Instrukcja przekazana Duriniemu na progu jego misji w Warszawie zawierała zarówno wezwania do stanowczej obrony statusu religii panującej, jak i liczne zachęty do szukania kompromisu, wybierania mniejszego zła, rozwagi i roztropności w podejmowanych działaniach, z myślą o dobru kraju osaczonego przez potężne mocarstwa (Instrukcja rozpoczyna się od refleksji nad okupacją Polski przez armię rosyjską - „Già le armate Russe stanno distrubuite in più parti del Regno pronte ad agire con violenza a ogni momento [--]”).

Pozornie trudna do rozwikłania sprzeczność między wezwaniem do bezkompromisowej gorliwości oraz dyplomatycznego umiarkowania ${ }^{18}$ była związana z zasygnalizowanym wyżej rozróżnieniem między sferą świecką i duchową, które w 1767 r. dostrzegano także w pretensjach dysydentów. Instrukcja z czerwca 1767 r. rozpoczynała się od jednoznacznego stwierdzenia: „zachowanie katolickiej wiary w Królestwie Polskim jest obecnie jedną z największych trosk Ojca Świętego"19. Stolica

17 „Continuandomi V.S. Illma coi suoi Numeri dei 4 andante i riscontri delle vicende della nuova Confederazione di codesto Regno e vedendo $\mathrm{N}$ [ostro] S[ignore] che deve perciò prenderne vieppiù serio timore la Corte, si conferma la S[ua] S[antità] nella opinione che aveva già concepita riguardo al contegno di V.S. Ill.ma cioè che ella in un sì critico emergente regoli ogni suo passo o discorso con tale cautela e circospezione da non cadere in sospetto né dell'una né dell'altra parte, per essere sempre in stato di sovvenire la Religione in quei migliori modi che le saranno possibili. Soprattutto invigili acciocché il Re sospenda l'esecuzione dei risultati dell'ultima Dieta, nel che l'attuale fermento della nazione può anche garantirlo dai rimproveri della Czarina", L.M. Torrigiani do A.M. Duriniego, Rzym, 28 V 1768, ASV, Archivio della Nunziatura di Varsavia 43, k. 453. Cyt. w: D. Caccamo, op. cit., s. 41-42. Edycja w: Acta Nuntiaturae Polonae, t. 52: Angelus Maria Durini (1767-1772), cz. 2: 23 IV 1768 - 14 II 1769, wyd. W. Kęder, Cracoviae 2017 (dalej: ANP 52/2), N. 373.

18 Domenico Caccamo (op. cit., s. 41) pisał, że to zasady tylko pozornie sprzeczne i że obie mogły służyć za praktyczną regułę postępowania nuncjusza. Na potwierdzenie przytoczył fakty z praktyki kurii rzymskiej, kiedy to stanowczym i bezkompromisowym deklaracjom towarzyszyła pewna łagodność praktycznych decyzji, uwzględniających kontekst polityczny danego problemu.

19 „Tra tutte le gravi cure dell'Apostolico Ministero della Santità di Nostro Signore quella, che presentemente eccita le più particolari sue sollecitudini, si è la preservazione della Religione Cattolica nel Regno di Polonia", Istruzione, k. 125v. 
Apostolska miała pełną orientację w fatalnym położeniu politycznym kraju, do którego skierowany został abp Durini. Wskazano na obecność w Polsce rosyjskich wojsk, na stosowany przez Rosję argument siły, na konfederacje dysydentów w Toruniu i Słucku oraz na realne ryzyko wymuszenia na nadchodzącym sejmie równouprawnienia niekatolików. Klemens XIII wyrażał przekonanie, że obce potęgi nie cofną się przed niczym, by osiągnąć cel, a „niewinny katolicki naród” (,innocente cattolica nazione") nie jest dziś w stanie oprzeć się ich przemocy, jak to czynił nieraz w przeszłości. Rzeczpospolita stoi przed koniecznością „znoszenia gwałtów, które obecnie na nią spadają i musi obawiać się gorszych nieszczęść, o ile nie zdoła na nadchodzącym sejmie jakimś sposobem pozyskać sobie łaski owych potęg"20. W Instrukcji przyznawano jednocześnie, iż trudno sobie wyobrazić, w jaki sposób można obłaskawić obce mocarstwa wspierające dysydentów, zachowując jednocześnie integralność praw katolicyzmu. W wolnej dyspucie dysydenci nie znaleźliby argumentów na swoją korzyść, jednak rozstrzyga przemoc stosowana przez ich protektorów ${ }^{21}$.

W tym kontekście pojawiło się po raz pierwszy wezwanie nuncjusza, aby zachowywał najwyższą ostrożność w podtrzymywaniu morale katolików za pomocą argumentacji przeciw pretensjom dysydentów, by nie doprowadzić do nadmiernej irytacji „pewnych siebie” („baldanzosi") prześladowców ${ }^{22}$. Dyrektywa była jednak daleka od jednoznaczności, gdyż natychmiast jej autor dodawał: dobry katolik powinien raczej narazić się na cierpienie i prześladowanie, niż dopuścić do ogłoszenia praw przynoszących trwałą szkodę dla Kościoła ${ }^{23}$. Takie były ogólne

20, ,Polonia] trovasi nella dura necessità di sopportare le violenze che ora l'opprimono e di temere delle molto maggiori e più funeste, qualora non le riesca di conciliarsi nella futura Dieta, con qualche onesto disimpegno, la pristina grazia delle Potenze medesime", ibidem, k. 126v.

21 „Le ragioni, che ci assistono, possono essere bensì valevoli a incoraggiare i bene affezionati alla Religione, ma non già a disarmare gli ostinati oppositori”, ibidem.

22 „Dovrà dunque Mons. Nunzio prevalersene [mowa o racjach stojaccych po stronie katolików] opportunamente e comunicarle a chi sia in istato di farne buon uso, sempre però colla dovuta cautela e prudenza per non irritare maggiormente i baldanzosi persecutori”, ibidem, k. 127. Porównanie z oryginałem w ASV, Segr. Stato Polonia 238, k. 126v. każe opowiedzieć się za „baldanzosi persecutori”, zamiast „féldansozi persecutori”, jak widnieje w transkrypcji opublikowanej w ANP.

${ }^{23}$ „ben vede Mons. Nunzio non potersi né da noi né da ogni altro buon Cattolico o accordare o tollerare [mowa o dalszych ustępstwach na rzecz dysydentów], e forza essere di piuttosto soffrire violenza che di apprestare le mani a condiscendere a pazioni che siano per essere d'irreparabile e perpetuo danno", Istruzione, k. 127v. W ANP zamiast „tollerare” występuje „vollerare”, zamiast „pazioni” - „pasioni”). 
wskazania („le massime generali”) dla króla, biskupów, dla dworu, lecz znów uzupełniono powyższe uwagi zachętą do roztropności: z dwojga niedających się uniknąć nieszczęść należy „wybrać mniejsze zło”. W tym miejscu przekazano nuncjuszowi dokładną listę ustępstw, których mogli domagać się dysydenci, a które były absolutnie nie do zaakceptowania. W dziewięciu kwestiach domagano się stanowczego przeciwdziałania, za cenę „zerwania sejmu lub innych równie poważnych konsekwencji”. Były to: 1) ewentualna próba dopuszczenia dysydentów do kandydowania do korony królewskiej w Polsce; 2) zwolnienie króla z obowiązku poślubienia katoliczki; 3) utrudnienie lub zakazanie konwersji na katolicyzm - z protestantyzmu lub prawosławia; 4) zniesienie praw przeciw apostazji w przypadku unitów lub konwertytów z protestantyzmu, którzy pragnęliby powrócić do swych wcześniejszych wspólnot wyznaniowych; 5) ponowne odebranie katolikom kościołów, które przejęli wcześniej z rąk prawosławnych czy protestantów; 6) pozwolenie protestantom na kult publiczny poza miejscami dotąd dozwolonymi; 7) na nieograniczoną budowę prywatnych oratoriów, oraz 8) na małżeństwa mieszane, w których dzieci wychowywano by w religii danego rodzica, według rozróżnienia płci; 9) uprawnienie dysydentów do pełnienia funkcji publicznych, na równi z katolikami ${ }^{24}$.

W tych kwestiach nuncjusz miał zachęcać biskupów oraz wszystkich gorliwych patriotów do stanowczego oporu. Polecano abpowi Duriniemu pobudzanie sumień senatorów i posłów, by nie wahali się całkowicie zdać na Bożą Opatrzność i nie zgadzali się na żaden kompromis co do głównych zasad stanowiących o statusie katolicyzmu jako religii panującej, nawet za cenę prześladowania ${ }^{25}$. Przyznawano jednocześnie, że zerwanie sejmu mogłoby mieć fatalne konsekwencje dla nieszczęśliwego kraju, dlatego mimo wszystko należy, nawet w przypadku przeforsowania niektórych wymienionych dopiero co punktów, szukać „uczciwego kompromisu" („onesto disimpegno”) ${ }^{26}$.

Rzecz jasna, inicjatorem ewentualnego kompromisu nie mógł być nuncjusz, który miał oficjalnie stanowczo bronić katolicyzmu. Przewidywano jednak, że sugestie kompromisowych rozwiązań zostaną zaproponowane przez dwór królewski, a wówczas nie należy ich bezwzględnie odrzucać. Rozeznaniu nuncjusza pozostawiono ocenę, czy można przyjąć

${ }^{24}$ Istruzione, k. $128-128 \mathrm{~V}$.

${ }^{25}$ Ibidem, k. 129.

${ }^{26}$ „Per altro le conseguenze della rottura della Dieta sarebbero si funeste alla misera infelice nazione, che per ogni conto dovrà evitarsi, e Nostro Signore si augura, che anche per alcuni dei Punti già accennati possa piuttosto cercarsi qualche onesto disimpegno, che venire a tale calamitosa estremità", ibidem, k. 129v. 
pewne ustępstwa wobec dysydentów, o ile nie wyniknie z nich „prawdziwa i bezpośrednia szkoda" dla katolicyzmu, by uniknąć większego zła ${ }^{27}$. Kilku wymienionym wyżej kwestiom poświęcono dłuższą refleksję. Co do punktu piątego, dotyczącego zwrotu kościołów - uznano, że w niektórych przypadkach, jeśli istniało podejrzenie przejęcia świątyni przez katolików przemocą, komisja mieszana mogłaby zaopiniować daną sprawę i poddać ocenie stosownego trybunału lub sejmu ${ }^{28}$. Dłuższy wywód dotyczył punktu siódmego, tj. pozwoleń na budowy prywatnych oratoriów dysydenckich, które popierali nawet niektórzy katolicy liczący na przyciągnięcie osadników. Po wymienieniu wszystkich argumentów przeciw takim zabiegom o zwiększenie populacji dysydenckiej w kraju zwrócono uwagę nuncjusza na możliwość delikatnego kompromisu także w tej kwestii ${ }^{29}$. Problem małżeństw dysydentów i małżeństw mieszanych Instrukcja pozostawiała do późniejszej oceny Ojca Świętego - nie tyle co do zasady nadrzędności katolickiego prawa kanonicznego, ile co do możliwości kompromisu z niektórymi oczekiwaniami dysydentów, np. zawierania małżeństw przed własnym ministrem-duchownym ${ }^{30}$. Omówiono w Instrukcji także skutki pewnych ustępstw poczynionych na rzecz dysydentów przez polskich biskupów na sejmie $1766 \mathrm{r}^{31}$, by następnie przejść do punktu szczególnie zapalnego - równouprawnienia na płaszczyźnie prawa cywilnego. Materie świeckie, nad którymi miał debatować sejm, poddane zostały wspominanej już zasadzie nieingerencji nuncjusza, z wyjątkiem równouprawnienia dysydentów, która to kwestia interesowała zarówno państwo, jak i Kościół:

Co do kwestii, które mogłyby być zaproponowane na sejmie, a które dotyczą wyłącznie sfery politycznej i cywilnej Rzeczypospolitej, bez żadnego związku z religią, jak np. likwidacja dwóch komisji skarbu i wojska, przywrócenie

27 „Tali disimpegni si proporranno forse dalla Corte, dai Ministri politici e da altri, ma non mai dal Nunzio, il quale anzi è in obbligo di garantire in tutto e in ogni tempo e circostanza la Religione. Ma quando in alcuno di tali disimpegni potesse egli scorgere che le grazie da accordarsi ai Dissidenti non potessero risultare in vero o diretto danno della Religione Cattolica, dovrà egli pazientare che prenda piede o si adotti nella Dieta, qualora giudicar si possa, che le Corti protettrici siano per chiamarsene soddisfatte e per desistere dalle altre più gravose e pregiudizievoli pretensioni”, ibidem, k. 130.

${ }^{28}$ Ibidem, k. 130v.-131. Por. W. Kęder, Stolica Apostolska, s. 201, jednak bez wzmianki o owym branym pod uwagę ustępstwie.

${ }^{29}$ Istruzione, k. 131v.-134.

30 Ibidem, k. 134-137.

${ }^{31}$ Ibidem, k. 137-139. Por. M.C. Łubieńska, Sprawa dysydencka 1764-1766, WarszawaKraków 1911, s. 118-147; J.T. Łukowski, The Papacy, Poland, Russia and Religious Reform, 1764-8, „Journal of Ecclesiastical History” 36, 1988, 1, s. 82. 
autorytetu hetmanowi wielkiemu, przywrócenie do łask księcia Radziwiłła czy inne podobne [--], co do których istnieją spory, albo które bądź dwór, bądź opozycja chciałyby zaproponować bez uchybiania religii, jego ekscelencja nuncjusz będzie bardzo uważał, by nie angażować się po żadnej ze stron, nawet jeśli uznałby to za korzystne bądź dla republiki, bądź dla dworu; wszystko po to, by nie wzbudzić podejrzeń ani na dworze, ani wśród opozycji, ani u reszty narodu; co więcej, [nuncjusz] powinien dołożyć wszelkich starań, aby swoją obojętnością w podobnych materiach zjednać sobie sympatię i zaufanie wszystkich. Powinien bardziej zaangażować się na rzecz dworu jedynie w wypadku, gdyby opozycja przebrała miarę i podjęła próbę detronizacji króla, przed czym niech Bóg broni. Ale równouprawnienie, którego domagają się dysydenci, i doskonała równość z katolikami co do możliwości pełnienia funkcji w państwie, są to kwestie, które muszą w stopniu najwyższym budzić zainteresowanie Kościoła, dlatego co do nich nuncjusz powinien być stale czujny i uważny ${ }^{32}$.

Jednak nawet $\mathrm{i}$ to zdecydowane stanowisko przeciw pretensjom dysydentów zostało uzupełnione o refleksję nad możliwym kompromisem. Ponieważ to król jest rozdawcą dóbr i urzędów, trzeba zrobić wszystko, by prawo nie zezwoliło na obejmowanie urzędów przez dysydentów, ponieważ w takiej sytuacji obce potęgi zawsze zdołają wymusić na królu nominacje zgodne $\mathrm{z}$ ich zamierzeniami. W interesie króla i narodu pozostaje więc zachowanie stanowisk wyłącznie dla katolików.

32 „Su di quelle, che potessero proporsi nella Dieta, che unicamente risguardino lo stato politico e civile della Repubblica senza niuna relazione alla Religione, come sarebbe la soppressione delle due Commissioni del Tesoro e della Guerra, il ristabilimento del Gran Generale, la reintegrazione del Principe di Radzivil, o altre simili cose politiche ed economiche, che fra diversi sentimenti si contrastano, o altre che la Corte per una parte, e i malcontenti dall'altra fossero per tentare senza pregiudizio della religione, Mons. Nunzio starà ben cauto per non ingerirsene in conto alcuno, guardandosi dall'aderire a qualunque partito, quand'anche lo giudicasse ridondare in utilità della Repubblica o della Corte; e ciò affine di non ingerire sospetti o nella Corte, o nei Malcontenti, o nel resto della Nazione, dovendo egli anzi porre ogni studio per conciliarsi colla sua indifferenza in simili materie l'animo e la confidenza di ciascuno, e soltanto dovrà interessarsi per la Corte, qualora i Malcontenti giungessero all'eccesso, che Dio non voglia, di tentare la detronizzazione del Re. Ma l'abilitazione, che richiedono i Dissidenti, e la perfetta eguaglianza che vorrebbero coi Cattolici negli impieghi civili, è un punto che non può a meno di non interessare sommamente anche la Religione sicché per questo conto dovrà Mons. Nunzio starne in continua vigilanza e attenzione", Istruzione, k. 139-139v. Porównanie z oryginałem w Tajnych Archiwach Watykańskich (ASV) ponownie wykazało usterki w transkrypcji w ANP (ASV: „la reintegrazione del Principe di Radzivil”, ANP: „la integrazione del Principe Radziwil”; ASV: „Mons. Nunzio starà ben cauto”, ANP: „ben canto”; ASV: „starà ben cauto per non ingerirsene in conto alcuno”, ANP: „starà ben canto per ingerirsi in conto alcuno”). 
Jednocześnie - napominała Instrukcja - z pewnością nie braknie w otoczeniu króla osób pragnących przypodobać się carycy, a więc takich, które będą gotowe poprzeć prawne zagwarantowanie równouprawnienia dysydentów. Wynika stąd konieczność zachowania przez nuncjusza szczególnej czujności ${ }^{33}$. Po podsumowaniu znanych już z minionych lat propozycji nowych ustaw przychylnych dysydentom, Stolica Apostolska zalecała nuncjuszowi Duriniemu stanowcze przeciwdziałanie takim projektom, ale z jednoczesną możliwością kompromisu, włączając w jego zakres nawet ,jedno-dwa miejsca w senacie i cztery do sześciu w sejmie" ${ }^{34}$. Korzystanie z tych zaleceń Stolicy Apostolskiej zalecano nuncjuszowi z największą dyskrecją:

W sumie we wszystkich tych ustaleniach, które dotyczą państwa, powinno się iść na najmniejsze z możliwych ustępstwa. Nuncjusz zaś nie powinien być postrzegany przez naród jako zbyt zaangażowany w takie detale, ponieważ szlachta jest bardzo wrażliwa na punkcie własnych interesów i mogłaby rozjątrzyć się przeciw niemu i oskarżyć go o zbytnią ustępliwość. W takiej sytuacji mogłaby mniej słuchać rad nuncjusza co do kwestii istotniejszych i bardziej kluczowych dla sprawy religii ${ }^{35}$.

Stolica Apostolska wiosną 1767 r. była więc pewna, że ustępstwa na rzecz dysydentów podczas nadchodzącego sejmu mogą być nieuniknione ${ }^{36}$. Stąd wynikała konieczność szczególnie zręcznych działań dyplomatycznych nuncjusza i mądrego wycofywania się z pozycji, których nie da się obronić - „teren” należało tracić jedynie małymi krokami i to wtedy, gdyby było już pewne, że nie ma innego wyjścia („,colla speciale avvertenza di non perdere che a poco a poco quel terreno che non potrà ritenersi"). Papieżowi zależało także, by nie poddawać ustępstw na rzecz dysydentów gwarancji obcych potęg, które zawsze nadużywały podobnych sformułowań w celu dalszego zniewalania kraju, dysponując siłami znacznie przewyższającymi polską zdolność obronną („la forza che hanno in mano di gran lunga superiore a quella della nazione") ${ }^{37}$.

33 Ibidem, k. 140-140v.

${ }^{34}$ Ibidem, k. 141v.

35 „In somma in tutti questi temperamenti, che hanno rapporto allo stato civile si conceda sempre il meno che sia possibile. Né Mons. Nunzio dovrà mostrarsi colla Nazione connivente in tali particolari, perché essendone essa gelosissima come di cose che toccano il proprio interesse, potrebbe inasprirsi contro di lui e accusarlo di troppo condiscendente e così seguir meno il suo consiglio, e le sue premure negli altri casi più essenziali al servigio della Religione", ibidem, k. 141v.

36 J.T. Łukowski, op. cit., s. 83.

${ }^{37}$ Istruzione, k. 141v.-142v. 
Nuncjusz miał także przeciwdziałać ewentualnym pomysłom zawiązania w czasie nadchodzącego sejmu konfederacji generalnej. Społeczeństwo szlacheckie Rzeczypospolitej było zbyt podzielone i słabe, by przy pomocy konfederacji oprzeć się przemocy zewnętrznej, a w takiej sytuacji Rosja wykorzystałaby możliwość uchwalania praw większością głosów do skorumpowania lub zastraszenia odpowiedniej liczby posłów:

Jeśli w czasie dyskusji nad różnymi punktami, które zostaną zaproponowane podczas sejmu, doszłoby do takiego poruszenia zarówno wśród opozycji, jak i dysydentów, że zapragnęliby zawiązać w królestwie konfederację generalną, [trzeba pamiętać], że w obecnych warunkach papież uważa ją za zbyt niebezpieczną i dlatego nuncjusz powinien rozważnie zaangażować się, by do jej zawiązania nie doszło. Gdyby naród dysponował odpowiednimi siłami, odwagą i jednością zapatrywań, [konfederacja] byłaby doskonałym środkiem oparcia się gwałtom prześladowców, ale przy obecnym poniżeniu, w którym się znajduje, o wiele więcej należałoby się obawiać, niż żywić w związku z nią nadzieję ${ }^{38}$.

Co do przewidywanego sposobu prowadzenia obrad sejmowych, papież dopuszczał ewentualne powierzenie różnych kwestii szczegółowych specjalnym komisjom, które następnie miałyby referować swe konkluzje sejmowi. Nuncjusz miał się w takim przypadku starać o wybór do komisji właściwych osób ${ }^{39}$. W wypadku konieczności poczynienia nadmiernych ustępstw wobec dysydentów papież zalecał raczej zgłoszenie protestu przez biskupów i gorliwych świeckich, niż zerwanie sejmu ${ }^{40}$. Po kilku wskazówkach protokolarnych związanych ze stosunkiem nuncjusza do ambasadorów innych władców, ostatnie akapity Instrukcji powtarzały apel o rozwagę i umiarkowanie:

Tymczasem niech ciągłą troską [nuncjusza] będzie pozyskanie zaufania biskupów, aby trwali mocno w kościelnej gorliwości, byli zgodni i posłuszni

38 „Che se nella discussione de' vari punti, che si proporranno nella Dieta accadesse che la fermentazione degli animi dei malcontenti combinati coi Dissidenti giungesse fino al segno di volere una Confederazione generale nel Regno, questa si riconosce da Nostro Signore nelle odierne circostanze come troppo pericolosa, e perciò Mons. Nunzio dovrà prudentemente adoprarsi acciò non si eseguisca. Se la nazione fosse in diverso stato di facoltà di forze di coraggio e di uniformità di sentimenti, potrebbe esser questo un'ottimo mezzo per resistere alle violenze degli oppressori, ma nell'attuale avvilimento in cui ella si ritrova, molto più vi sarebbe di che temere, che di sperarne", ibidem, k. 142v.

39 Ibidem, k. 143.

40 „Nostro Signore rimette alla prudenza di Mons. Nunzio di accudire piuttosto a qualche contraria protesta dei Vescovi e dei più zelanti Cattolici, che permettere una formale rottura della Dieta", ibidem, k. 143v. 
dyrektywom nuncjatury. Jeśli ktoś o niespokojnym duchu lub nadmiernej gorliwości podejmowałby kroki zbyt daleko idące, grożące nadmierną irytacją potęg protegujących dysydentów oraz wojsk rosyjskich, które znajdują się obecnie w Polsce, wskazane będzie sprowadzenie go na drogę rozwagi i umiarkowania, by bez potrzeby i nierozważnie nie pogrążyć w ten sposób narodu w większych niebezpieczeństwach i kłopotach.

Do tych samych zasad roztropności należy przekonywać zakony, zakładając oczywiście, że nie ma to oznaczać zmniejszenia ich przywiązania do Kościoła oraz gorliwości, z jaką powinny starać się o jego pomyślność. Tego rodzaju roztropność powinna polegać głównie na powstrzymaniu się od działań, które mogłyby oznaczać obrazę dysydentów i ich protektorów, oraz na traktowaniu ich w duchu chrześcijańskiej łagodności i dobrotliwości. [--] Podobne zachowanie nuncjusza zyska mu także przychylność dworu i ministerium, gdy okaże się, że instrukcje Ojca Świętego i jego [sekretarza stanu], oprócz niezmiennej troski o dobro religii, mają na celu rozważne oddalenie tych poważnych niebezpieczeństw, które niosłyby szkodę dworowi i narodowi, i pobudzają na wszelkie sposoby do troski o zapewnienie królestwu trwałego spokoju ${ }^{41}$.

Jak widać, Instrukcja Stolicy Apostolskiej dla nuncjusza zawierała inspiracje do radykalnej obrony praw katolicyzmu w Rzeczypospolitej, aż po narażenie się na prześladowanie ze strony potęg dążących do przyznania szerokiego zakresu praw dysydentom. Obfitowała jednak w równie stanowcze sugestie umiarkowanego i rozważnego postępowania w kraju, który nie był w stanie zrównoważyć przewagi militarnej

41 „Intanto sua continua cura sarà di cattivarsi l'animo dei Vescovi per tenerli saldi nelle massime di Zelo Ecclesiastico, concordi fra loro e dipendenti dalle direzioni della Pontificia Rappresentanza. Se taluno di spirito o zelo inquieto facesse dei passi troppo avanzati, dai quali ne potesse risultare una maggior irritazione nelle Potenze protettrici dei Dissidenti, e nelle Truppe Russe, che sono attualmente in Polonia, converrà ricondurlo sul sentiere della prudenza e della moderazione per non precipitar così la nazione senza necessità alcuna e male a proposito in maggiori pericoli e disagi. Le stesse massime di prudenza dovrà inculcare agli ordini regolari, ben inteso sempre, che le medesime non vadano punto a diminuire quel costante attaccamento, che essi debbono professare, alla nostra Santa Religione, e quel impegno, con cui debbono promuoverne i vantaggi, ma una tale prudenza dovrà principalmente consistere in astenersi da qualunque contestazione o ingiuria, che offender potesse le persone dei Dissidenti, o dei loro fautori, e protettori, trattandoli sempre con spirito di cristiana mansuetudine e dolcezza. [--] Un simile contegno di Mons. Nunzio piacerà anche alla Corte e al Ministero politico, vedendo che le Istruzioni del Sommo Pontefice e del suo ministro non sono dirette che, salva sempre l'indemnità della Religione, ad allontanare prudentemente quei maggiori pericoli, che ridonderebbero a danno della Corte medesima, e della nazione, nel mentre che con ogni studio si procura in ogni modo possibile la soda tranquillità del Regno", ibidem, k. 144-144v. 
ingerujących w jego poczynania sąsiadów. Niektóre fragmenty Instrukcji wydają się wręcz ze sobą sprzeczne, jak choćby wezwanie do poświęcenia wszystkiego dla obrony religii z jednoczesnym nakazem studzenia zapału nadmiernych zelantów, których działanie mogłoby jedynie bardziej rozjątrzyć obce mocarstwa. Zapewne może na tym właśnie miał polegać geniusz papieskiego dyplomaty, by w zależności od oceny sytuacji wybrać jeden lub drugi sposób postępowania.

Jednocześnie warto się dodatkowo zastanowić nad głębszą wymową wspomnianych przeciwstawień. Z perspektywy Stolicy Apostolskiej nie istniało nic bardziej oczywistego, jak konieczność obrony katolicyzmu i jego prerogatyw. Tego rodzaju wezwania w instrukcji dla nuncjusza nie mogą nikogo dziwić. Natomiast zaskakiwać może często powracające wezwanie do umiarkowania oraz zgoda na ustępstwa, byle tylko nie pogrążać nieszczęśliwej Rzeczypospolitej w jeszcze gorszym kryzysie. Te wezwania bardzo różnią się od zwykłej w wypowiedziach Stolicy Apostolskiej stanowczości w obronie zasad. Stolica Apostolska, świadoma dramatycznej sytuacji kraju zniewolonego przez obcą przemoc, wzywała nuncjusza do postawy kompromisu i wyboru mniejszego zła. W innej, idealnej sytuacji politycznej, bezwzględnym imperatywem byłaby stanowcza obrona praw katolicyzmu. Nuncjusz Durini został jednak posłany do kraju, w którym idealne warunki nie istniały.

\section{Preludium - dramatyczne drugie półrocze 1767 roku}

Pierwsze istotne informacje przesłane przez nuncjusza Duriniego z Warszawy do Rzymu dotyczyły kandydatury ks. Gabriela Podoskiego na stolicę prymasowską w Gnieźnie ${ }^{42}$. Korzystając w znacznej mierze z dokumentacji zgromadzonej jeszcze przez poprzednika, Antonia Eugenia Viscontiego, Durini potwierdzał pozytywną opinię o przyszłym prymasie. Zastrzegał, że jest „zbyt nowy na swym urzędzie, by wypowiedzieć w pełni właściwy sąd o Podoskim, ale na podstawie kilku osobistych rozmów dostrzega w nim finezję i subtelność talentu, który go wyróżnia,

42 A.M. Durini do L.M. Torrigianiego, 12 VIII 1767, ASV, Segr. Stato Polonia 280, k. 154-155v., 158-158v. Zob. także Archivio Storico della Diocesi di Como, Archivio della Famiglia dei Conti Durini di Monza, Nunziatura di Polonia di Mons. Angelo Maria Durini (dalej: AD), t. 1, s. 2-4. Listu tego Theiner nie włączył do swego wyboru korespondencji nuncjusza. Opierając się na tej edycji Etienne Duda także pomija ową depeszę w przywoływanym wyżej artykule, s. 152-153. List został przepisany w ANP 52/1, N. 33. 
jako że ma duży wpływ na wszystkie sprawy"43. Przyszły prymas z pewnością potrafił robić dobre wrażenie, co początkowo zwiodło Duriniego. Nuncjusz wziął za dobrą monetę jego zapewnienia o przywiązaniu do Stolicy Apostolskiej i religijnej gorliwości. Podoski zadeklarował, iż $\mathrm{w}$ jego rodzinie - w przeciwieństwie do niejednego polskiego możnego rodu - nigdy nie było przejść na protestantyzm czy prawosławie. Co więcej, doszło do uszu nuncjusza, iż ksiądz referendarz otrzymał reprymendę od Nikołaja Repnina za organizowanie prywatnych spotkań z konfederatami radomskimi bez wiedzy rosyjskiego ambasadora. Na upomnienie miał odpowiedzieć odważnym stwierdzeniem, iż „jeśli godność prymasowska musiałaby go kosztować utratę uczciwości i prawości, jest gotów pozostać referendarzem koronnym"44. Durini zatem potwierdził pozytywną opinię o Podoskim, przesłaną do Rzymu jeszcze przez Viscontiego ${ }^{45}$.

Jak wiadomo, Podoski, jako bliski współpracownik Repnina, od listopada 1766 r. odgrywał istotną rolę w organizowaniu opozycji antykrólewskiej, a zwłaszcza w nakłanianiu znaczących w niej postaci do udziału w konfederacji radomskiej. Stanisław August starał się wyperswadować Repninowi tego kandydata do prymasostwa, m.in. z uwagi na jego zbyt manifestacyjne okazywanie sympatii dysydentom oraz swobodę obyczajów, która raziła opinię publiczną ${ }^{46}$. Rosyjski ambasador wymusił jednak na królu zgodę na przedstawienie kandydatury Podoskiego. Dzień po śmierci prymasa Władysława Łubieńskiego Repnin za pośrednictwem brata królewskiego, podkomorzego koronnego Kazimierza Poniatowskiego, dał królowi do zrozumienia, że żadne racje nie odmienią jego decyzji o promocji wybranego kandydata ${ }^{47}$. Dwa dni później Stanisław August zadeklarował wobec Katarzyny II, że postąpił zgodnie

43 „Io sono troppo nuovo in quest'offizio per poter formare adeguato concetto del Podoski: quello che posso dirne a V.E., si è, che in varie conversazioni seco avute ho ravvisato in lui una finezza, e sublimità di talento, che lo distingue, sicché influisce grandemente in tutti gli affari”, A.M. Durini do L.M. Torrigianiego, 12 VIII 1767, ASV, Segr. Stato Polonia 280, k. 154v.

44 „anzi che avvilirsi rispose coraggiosamente, che se la Dignità Primaziale doveva costargli tanto di renunziare all'onestà ed alla probità, egli era pronto di tornare ad essere Referendario della Corona", ibidem, k. 155.

45 „Tutto ben ponderato non posso a meno di non uniformarmi al sentimento di Mons. Visconti per la sollecita spedizione delle Bolle", ibidem, k. 155-155v.

46 E. Rostworowski, Podoski Gabriel Jan h. Junosza, w: PSB, t. 27, Wrocław 1982-1983, s. 149 nn.; W. Konopczyński, op. cit., t. 1, s. 169-170.

${ }^{47}$ N. Repnin do K. Poniatowskiego, Warszawa, 22 VI 1767, ASV, Segr. Stato Polonia 280, k. 121r. (Theiner, s. 162 [dokument LXIII]). 
z wolą ambasadora i „sprawił jej przyjemność”, podpisując nominację ${ }^{48}$. 25 czerwca 1767 r. niezwykle pochlebną opinię o Podoskim przekazał nuncjuszowi Viscontiemu biskup krakowski Kajetan Sołtyk, nazywając referendarza „swym przyjacielem” i wyrażając nadzieję, że jako prymas oraz człowiek zaufania sąsiednich mocarstw pomoże przeciwstawić się pretensjom dysydentów na nadchodzącym sejmie ${ }^{49}$.

Opinie wyrażone o Podoskim przez abpa Duriniego w początkach sierpnia 1767 r. oraz późniejsze rozczarowanie mogą sugerować, że jego pierwsza, tak szybko sformułowana ocena, wynikała z pochlebnych dla kandydata zapewnień osób trzecich (może bpa Sołtyka?), którym nuncjusz zaufał. Do błędu przyznał się w depeszy z 21 listopada 1767 r., zrzucając całą winę na swego poprzednika, Antonia Eugenia Viscontiego:

W zeszłym tygodniu pojawiły się tu teksty Woltera, szkodzące wierze katolickiej i otwarcie przychylne dysydentom. Repnin czytał je, podkreślając własne zadowolenie, a pewien biskup (horrendum dictu) mu przyklaskiwał. ów biskup to prymas. Dowiedziałem się o tym fakcie od kogoś, kto usłyszał to od naocznego świadka. Mówi się także, ale tego już nie jestem pewien, że prymas od swej konsekracji nie odprawił ani jednej mszy św. Niestety uświadamiam sobie, że nie znałem go, ani nie mogłem go znać w pierwszych dniach mojej nieszczęśliwej służby jako nuncjusz. To był obowiązek Mons. Viscontiego, który przez siedem lat mógł go dobrze przenicować, i Mons. Visconti zda $\mathrm{z}$ tego sprawę Bogu ${ }^{50}$.

Paradoksalnie więc to król - oceniany przez Duriniego bardzo krytycznie - początkowo odradzał kandydaturę Podoskiego, zalecał ją

48 Stanisław August do Katarzyny II, Warszawa, 24 VI 1767 [nr 37], w: Correspondance de Stanislaas-Auguste avec Catherine II et ses plus proches collaborateurs (1764-1796), wyd. Z. Zielińska, Kraków 2015, s. 117 (komentarz na s. 115-116).

${ }^{49}$ K. Sołtyk do A.E. Viscontiego, Borzencin, 25 VI 1767, ASV, Segr. Stato Polonia 280, k. 136r. (Theiner, s. 162 [dokument LXIV]). Por. E. Rostworowski, op. cit., s. 152-153.

50 „Nella settimana scorsa capitarono qui dei versi di Voltaire ingiuriosi alla Fede Cattolica, ed apertamente favorevoli ai Dissidenti. Il Repnin li leggeva con enfatica compiacenza, ed un vescovo (horrendum dictu) applaudiva. Il vescovo è il Primate. Il fatto mi è stato accertato da uno, che lo sa da chi era presente. Quello che non so di certo, e che si dice si è, che il Primate non abbia più detto messa dopo la sua consacrazione. Purtroppo mi accorgo, che non lo conoscevo, né lo potevo conoscere sui primi giorni del mio infelice ministero. Quest'obbligo era di Mons. Visconti, che in sette anni poteva ben farne la notomia, e Mons. Visconti ne renderà conto a Dio", A.M. Durini do L.M. Torrigianiego, Warszawa, 21 XI 1767, ASV, Segr. Stato Polonia 280, k. 317v. Por. AD, t. 1, s. 84; Theiner, s. 242; ANP 52/1, N. 191 (z usterkami w transkrypcji). Prymas czytał rozprawę Essai historique et critique sur les dissensions des Eglises en Pologne, od 1770 r. na indeksie ksiąg zakazanych. Zob. Systematisches Repertorium zur Buchzensur 1701-1813. Inquisition, red. H. Wolf, Paderborn 2009, s. 426-427. 
natomiast niezwykle ceniony przez nuncjusza bp Sołtyk. Jednocześnie rozczarowany do prymasa nuncjusz nie postawił zarzutu fatalnej rekomendacji biskupowi krakowskiemu (czy też innym polskim biskupom lub możnym ${ }^{51}$ ), lecz swemu poprzednikowi, abpowi Viscontiemu. Nie wspomniał też o słuszności wcześniejszych ostrzeżeń Stanisława Augusta co do niegodnego stylu życia obecnego prymasa. Mógł, rzecz jasna, nie znać kulis nominacji prymasowskiej Podoskiego. Te zaś dobrze ilustrują całe skomplikowanie polskiej sceny politycznej w przededniu sejmu repninowskiego 1767-1768 r. oraz pomieszanie motywacji politycznych i religijnych, którymi umiejętnie sterował rosyjski ambasador ${ }^{52}$. Jednocześnie owo „rozczarowanie” nuncjusza prymasem może o tyle dziwić, że fatalna reputacja Podoskiego była dobrze znana zarówno Viscontiemu, jak i kurii rzymskiej ${ }^{53}$. Durini musiał dysponować kopiami depesz swego poprzednika, w których przestrzegał on króla i sekretarza stanu przed tą nominacją oraz dawał jasno do zrozumienia, że jest ona nieuchronna tylko na skutek nacisków Rosji. Do kwestii tej wypadnie jeszcze wrócić.

Depesze nuncjusza Duriniego od początku jego misji w Warszawie świadczą o energicznym zaangażowaniu się dyplomaty na rzecz opozycji antykrólewskiej, w której upatrywał jedynej szansy obrony statusu Kościoła katolickiego przeciw ambicjom politycznym dysydentów. 12 sierpnia, oprócz informacji o ks. Podoskim, donosił o możliwości publikacji argumentów polemicznych dotyczących pretensji innowierców i podkreślał zaangażowanie w tym względzie biskupa kijowskiego Józefa Andrzeja Załuskiego oraz niechęć do takich publikacji króla, który obawiał się drażnienia Rosji ${ }^{54}$.

Tydzień później opisał „genezę, rozwój i stan obecnej konfederacji [radomskiej]"55. Według relacji nuncjusza, król na sejmie 1766 r. nie

${ }^{51} \mathrm{~W}$ sierpniu 1767 r., bagatelizując nieco kwestię potrzeby uzyskania dokładnych opinii o Podoskim, podkreślał podziały w łonie polskiego episkopatu oraz elity świeckiej i niemożność uzyskania obiektywnej opinii co do kandydata na prymasostwo. A.M. Durini do L.M. Torrigianiego, 12 VIII 1767, AD, t. 1, s. 2; ANP 52/1, N. 33.

${ }^{52}$ Por. P. Zając, $W$ objęciach Oświecenia. Prymasostwo i prymasi w czasach stanisławowskich, w: Dzieje prymasostwa polskiego, red. Ł. Krucki, Gniezno 2017, s. 204-209. W artykule tym wykorzystano część dokumentacji spożytkowanej także w niniejszym przypisie.

${ }^{53}$ E. Rostworowski, op. cit., s. 152-153; por. E. Duda, op. cit., s. 149-150, 152. Na s. 152 Duda stwierdza, że Durini przekazywał sekretarzowi stanu smutne informacje o prymasie, nie wspomniał jednak o jego pierwszej pochlebnej opinii z początku sierpnia 1767 r., pominiętej u Theinera. Por. J.T. Łukowski, op. cit., s. 87.

54 A.M. Durini do L.M. Torrigianiego, Warszawa, 12 VIII 1767, ASV, Segr. Stato Polonia 280, k. 158; ANP 52/1, N. 33.

55 A.M. Durini do L.M. Torrigianiego, Warszawa, 19 VIII 1767, ASV, Segr. Stato Polonia 280, k. 166 (cały list także w AD, t. 1, s. 4-8). Por. Theiner, s. 218-219. Por. E. Duda, op. cit., s. 152-153; ANP 52/1, N. 43. 
spełnił obietnicy danej Katarzynie II w sprawie dysydentów. Przestraszony wizją utraty tronu, miał się zobowiązać do poparcia sprawy dysydenckiej i zadeklarować, że w wypadku jej porażki uzna się niegodnym korony i zgodzi na jej pozbawienie. Prosił jedynie o rozkaz dla ambasadora Repnina, by ściśle z nim współdziałał. Skutkiem tego miała być wspólna praca króla i ambasadora nad organizacją konfederacji dysydenckich w Słucku i Toruniu ${ }^{56}$.

Nie sposób dziś wskazać źródeł wiadomości, z których Durini korzystał, opisując postawę króla (swą relację nazwał „dokładną i szczerą” „esatta e sincera"). Nie sposób też każdej informacji nuncjusza konfrontować $\mathrm{z}$ innymi przekazami, jednak w tym przypadku można poczynić kilka uwag, korzystając z dodatkowych źródeł ilustrujących motywacje Stanisława Augusta. Faktem jest, iż jeszcze 5 października 1766 r. król tłumaczył Katarzynie II, dlaczego pełne równouprawnienie polityczne dysydentów w Rzeczypospolitej nie wchodzi w grę ${ }^{57}$. Niezrealizowanie na sejmie 1766 r. prodysydenckich żądań Katarzyny II skłoniło ją do użycia przeciw Rzeczypospolitej argumentu siły ${ }^{58}$. Zachowana korespondencja Repnina z Nikitą Paninem wyklucza zasadność podejrzeń o współpracę króla $\mathrm{z}$ ambasadorem $\mathrm{w}$ organizowaniu dysydenckich konfederacji ${ }^{59}$. Krótko po ich zawiązaniu stało się jasne, że sprawa dysydencka ma posłużyć Rosji do zniszczenia raz na zawsze wszelkich dążeń do reformy ustroju Rzeczypospolitej. Wkraczanie kolejnych rosyjskich oddziałów do Polski król odczytywał jako zapowiedź „czarnej” przyszłości ${ }^{60}$. Ostatecznie z końcem marca 1767 r. postanowił pójść drogą mniejszego zła i licząc na ocalenie części reform zjednać sobie ponownie carycę, obiecując współpracę w sprawie dysydenckiej ${ }^{61} .25$ marca król napisał w tej

56 „Spaurito il Re di Polonia da questi rimproveri e minacce della Czara le spedì inviato con suo chirografo, in cui non solo si obbligava a favorire la causa dei Dissidenti, ma anche si riprometteva di come bene riuscire nel [ $w$ registrze: di far riuscire il] loro intento; e quando ciò non fosse seguito si giudicava Egli medesimo indegno del Trono, da cui consentiva d'essere deposto; desiderava perciò che il Principe di Repnin di Lei Ministro a Varsavia si portasse ad agire seco di concerto", A.M. Durini do L.M. Torrigianiego, Warszawa, 19 VIII 1767, ASV, Segr. Stato Polonia 280, k. 166v.-167.

57 Stanisław August Poniatowski do Katarzyny II, Warszawa 5 X 1766, w: Correspondance de Stanislas-Auguste, s. 92-96 - nr 29.

58 Z. Zielińska, Polska w okowach „systemu pótnocnego”, 1763-1766, Kraków 2012, s. 588-589, $657 \mathrm{nn}$.

59 SIRIO, t. 67, Sankt Pietierburg 1889, s. 303-308, 328-329, 347-349, 359-362.

60 Stanisław August Poniatowski do Madame Geoffrin, Warszawa, 11 III 1767, w: Correspondance inédite du roi Stanislas-Auguste Poniatowski et de Madame Geoffrin (17641777), red. Ch. de Mouÿ, Plon, Paris 1875, s. 276.

${ }^{61}$ Stanisław August Poniatowski do Madame Geoffrin, Warszawa, 22 IV 1767, w: ibidem, s. 281. 
sprawie do Katarzyny II. W minucie listu do Panina z tego samego dnia widnieje przekreślony fragment: „niech [imperatorowa] zawsze będzie pewna, że nieustannie ożywiony najszczerszym do niej przywiązaniem, nie spełniłbym mego obowiązku i nie byłbym godny tytułu, który chciała, bym nosił, gdybym nie ujmował się za religią katolicką i za korzyściami politycznymi mojej ojczyzny"62. Uderza fakt, że w relacji nuncjusza motywacje króla ujęte są w diametralnie odmienny sposób.

Przechodząc do opisu opozycji antykrólewskiej, abp Durini informował sekretarza stanu, iż w odpowiedzi na działania dysydentów z końca marca 1767 r. zaczęto najpierw organizować katolickie konfederacje lokalne. Niektórzy ich uczestnicy protestowali przeciw rosyjskim gwałtom, inni z kolei liczyli na obalenie podjętych przez stronnictwo królewskie reform - „które choć pozornie dobre, przyznając zbyt wiele władzy królowi, godzą w wolności republiki, ich podtrzymanie zaś jest bardzo ważne dla religii"63. Nuncjusz relacjonował dalej: marszałkiem konfederacji generalnej ogłoszonej w Radomiu został wyznaczony przez carycę Karol Stanisław Radziwiłł, szybko jednak się okazało, że nadzieje katolików zostały poddane próbie bezwzględnych wymagań ambasadora Repnina, na którego protekcję liczyli. Ponieważ bez akcesu do konfederacji nie byłby możliwy udział w najbliższym sejmie, na taki akces zdecydowali się także hierarchowie - abp lwowski Wacław Sierakowski oraz biskupi krakowski Kajetan Sołtyk i kamieniecki Adam Krasiński, choć Repnin nie zaakceptował pierwotnej redakcji ich akcesu ${ }^{64}$. Nuncjusz był przekonany, że wykluczenie biskupów z obrad byłoby z korzyścią dla „króla i kilku senatorów, nieprzyjaciół kleru, i doprowadziłoby do definitywnego upadku religii w Polsce" ${ }^{65}$. Zachęcał także innych

62 „Veuille le ciel inspirer à l'impératrice les moyens de les abréger au possible et puisse-t-il être toujours présent à son esprit, que constamment animé du plus véritable attachement pour elle, je ne ferais pas mon devoir, je ne méritais pas le titre qu'elle a voulu que je porte, si je ne lui parlais pour la religion catholique et les avantages politiques de ma patrie", Stanisław August do N. Panina, Warszawa, 25 III 1767, [nr 35], $\mathrm{w}$ : Correspondance de Stanislas-Auguste, s. 113-114, przypis ${ }^{\mathrm{c}-}$.

63 „nuove leggi, le quali sebbene buone in apparenza, troppo attribuendo al $\mathrm{Re}$ ledono le libertà della Repubblica, la manutenzione delle quali importa moltissimo alla Religione", A.M. Durini do L.M. Torrigianiego, Warszawa, 19 VIII 1767, ASV, Segr. Stato Polonia 280, k. 168 (por. AD, t. 1, s. 6; ANP 52/1, N. 43). Ten fragment został opuszczony w edycji Theinera, s. 218.

64 Traduzione dell'Accesso alla Confederazione Generale di Radom di S.E. Mgr. Sierakowski, arcivescovo di Leopoli, di S.A. Mgr Principe Sołtyk, vescovo di Cracovia, duca di Severia, e di S.E. Mgr. Krasinski Vescovo di Kaminiec, die 15 Augusti 1767, ASV, Segr. Stato Polonia 280, k. 171-171v. Por. Theiner, s. 219 z odnośnikiem.

65 „cosa che forse non dispiacerebbe al Re, ed a parecchi senatori nemici del Clero, e che porterebbe certamente l'ultimo esterminio della Religione in Polonia", 
biskupów, by przyłączyli się do konfederacji z myślą o nadchodzącym sejmie i konieczności obrony praw religii. Kolejny raz wyraził też surowy osąd o królu:

W to, że król ugiął się na korzyść dysydentów, że dał na to słowo carycy, że to słowo jest dlań pretium coronae, nie sposób nie wierzyć. On sam dość jasno wytłumaczył to niejednemu mówiąc, że nie zamierza tracić korony, że pierwszym obowiązkiem króla jest nie dopuścić do upadku królestwa, że wystarczy mu ocalić to, co w religii katolickiej jest najistotniejsze, byle tylko pozostała wyznaniem panującym w Polsce, i w tym celu zadeklarował, że będzie nalegał na odnowienie prawa przeciw apostatom ${ }^{66}$.

Durini odtąd często spotykał się z biskupami, którzy m.in. długo debatowali nad właściwym sformułowaniem aktu swego akcesu do konfederacji radomskiej ${ }^{67}$. 0 ile nabrał nieufności do znacznej części polskiego episkopatu (część biskupów popierała króla, część chciała jedynie powrotu do dawnego układu politycznego, bez specjalnej dbałości o kwestie religijne), to z drugiej strony chwalił postawę Karola Radziwiłła, który deklarował gotowość obrony wiary nawet za cenę ponownej emigracji i podobno jeszcze w sierpniu 1767 r. zaczął w sekrecie gromadzić siły zbrojne, by stawić czoła Rosjanom ${ }^{68}$.

A.M. Durini do L.M. Torrigianiego, Warszawa, 19 VIII 1767, ASV, Segr. Stato Polonia 280, k. 169-169v. (Theiner, s. 219). Por. E. Duda, op. cit., s. 153, ANP 52/1, N. 43.

${ }^{66}$ „Che il Re si sia piegato alla parte dei Dissidenti, che ne abbia data parola alla Czara, che questa parola sia pretium coronae, sarebbe malensagine il dubitarne. Egli medesimo si è spiegato su questo proposito assai chiaramente con più di uno dicendo, che egli non intende di perdere la corona, e che il primo dovere di un Sovrano sia d'impedire la rovina del Regno, bastandogli di salvare ciò, che è il più sostanziale della Religione Cattolica, sicché rimanga dominante in Polonia, e a tal fine so, che si è anco dichiarato di voler insistere, perché si rinuovi l'editto contro gli apostati", A.M. Durini do L.M. Torrigianiego, Warszawa, 19 VIII 1767, ASV, Segr. Stato Polonia 280, k. 170-170v. Por. AD, t. 1, s. 8. Jest to kolejny fragment opuszczony w edycji Theinera, s. 219. A w ANP występują poważne usterki: począwszy od nagłówka, w którym list ten widnieje jako depesza Torrigianiego do Duriniego, a nie odwrotnie. W transkrypcji kluczowe słowo pojawia się w sensie dokładnie przeciwnym: ASV i AD: „perché si rinuovi l'editto contro gli apostati" (mowa o odnowieniu/potwierdzeniu edyktu przeciw apostatom), ANP: „perché si rimovi l'editto contro gli apostati” (mowa o zniesieniu edyktu przeciw apostatom).

${ }^{67}$ A.M. Durini do L.M. Torrigianiego, Warszawa, 24 VIII 1767, ASV, Segr. Stato Polonia 280, k. 176-178 (por. AD, t. 1, s. 9-10; Theiner, s. 219-220; ANP 52/1, N. 48 - brak transkrypcji, depesza jedynie zasygnalizowana, a w nagłówku błędnie L.M. Torrigiani do A.M. Duriniego, zamiast odwrotnie). Por. E. Duda, op. cit., s. 153.

${ }^{68}$ A.M. Durini do L.M. Torrigianiego, Warszawa, 26 VIII 1767, ASV, Segr. Stato Polonia 280, k. 178-179 (por. AD, t. 1, s. 10-12; Theiner, s. 220; ANP 52/1, N. 50). 
Już w pierwszych wrześniowych depeszach nuncjusz ukazywał obraz skrajnej polaryzacji postaw i przekonań w szlacheckim społeczeństwie Rzeczypospolitej. Król - stwierdzał - „uczynił się niewolnikiem Moskwy" i na nadchodzącym sejmie będzie wspierał dysydentów, byle tylko ocalić koronę. Ten polityczny wybór, zdaniem nuncjusza, miał źródło w osobistym indyferentyzmie religijnym monarchy, którego znakiem było choćby wprowadzenie protestantów do grona nauczycieli w Szkole Rycerskiej. Bez komentarza pozostawił Durini sugestię Kazimierza Poniatowskiego, iż „troska o religię jest czymś dobrym, lecz nadmierna gorliwość [,zelo smoderato”] okazana w niewłaściwym czasie zamiast przynieść korzyść, sprowadzić może na cały kraj gniew Moskwy" ${ }^{69}$. 16 września nuncjusz znów pisał o królu jako o „moskiewskim agencie", a jednocześnie dystansował się od opinii formułowanych w tym względzie przez poprzednika, abpa Viscontiego:

Nie wiem, jak mój poprzednik mógł napisać 29 lipca o królu, że podjął trudną decyzję ustąpienia we wszystkim zarówno dysydentom, jak i opozycji. Postulaty opozycji dotyczą obalenia nowych ustaw przyjętych przez ostatni sejm, a kilku co śmielszych zaczęło domagać się nawet detronizacji króla. Co do obalenia wspomnianych ustaw, król jest daleki od ustąpienia, przeciwnie, czyni wszystko dla ich ocalenia, gotów nawet do poparcia pretensji dysydentów, byle tylko pozostały w mocy. W ten sposób król działa właśnie jako agent Moskwy, co diametralnie różni się od opinii, którą dobrodusznie sformułował mój poprzednik, i tym sylogizmem zakończę moją depeszę $e^{70}$.

69 „Sempre più persisto nell'assertiva, che il Re si è reso così servo della Moscovia, che si trova posto nel bivio o di favorire i Dissidenti nella futura Dieta, o di azzardare la sua corona. Che a questo cimento Egli voglia esporsi non lo lascia credere né la sua condotta tutta coerente al sistema Russo, né lo spirito suo purtroppo libero in materia di religione, ed a questo proposito non posso dissimulare a V.E. che l'Indifferentismo ha preso qui tanto piede, che nella scuola Militare dei Cadetti eretta nell'ultima Dieta parecchi dei Maestri, e direttori sono Luterani o Calvinisti. [--] Che poi il Re cammini d'accordo colla Moscovia, oltre gli indizii dati a V.E. ne' miei passati dispacci, lo arguisco ancora da un discorso fattomi dal Principe Gran Ciambellano di lui Fratello domenica mattina nella camera del Re. Dopo avermi Egli esagerato il zelo mostrato da S.M., e da tutta la casa Poniatowski nell'ultima Dieta per la religione Cattolica, disse, che sarebbe bene l'adoperarsi per la religione senza alcun riguardo, se le circostanze presenti lo permettessero, ma che un zelo smoderato fuori di tempo, anzi che produrre un bene, partorirebbe un maggior male, esponendo tutto il Regno, al furore dei Moscoviti", A.M. Durini do L.M. Torrigianiego, Warszawa, 2 IX 1767, ASV, Segr. Stato Polonia 280, k. 184 (por. AD, t. 1, s. 12-14; ANP 52/1, N. 63). Cały akapit opuszczony w edycji Theinera.

70 „Del Re non so come il mio antecessore coi Numeri dei 29 Luglio scaduto ha potuto dire, che 'egli abbia preso il duro partito di lasciar correr tutto riguardo alle 
Warto zauważyć, że abp Visconti napisał cytowany przez Duriniego list krótko przed wyjazdem z Warszawy, zatem mając doświadczenie kilku niezwykle burzliwych lat służby dyplomatycznej w Rzeczypospolitej, a zwłaszcza sejmu 1766 r. i jego politycznych konsekwencji, obserwował też sytuację w kraju w okresie zawiązywania się konfederacji w Słucku, Toruniu i Radomiu. Kończąc swą misję w Warszawie i komentując rolę nuncjusza w ówczesnych warunkach, podkreślał zarówno konieczność stanowczych działań w obronie katolicyzmu, jak i rozwagi oraz umiarkowania w codziennej praktyce poczynań dyplomatycznych. Była to odpowiedź na zachętę sekretarza stanu do większej „gorliwości i odwagi" - Visconti zgadzał się ze swym zwierzchnikiem, lecz sugerował odpowiednie „dozowanie” stanowczych gestów, „żeby nie przeciąć całkowicie ostatniej nici nadziei, która może doprowadzić do stopniowego obniżenia napięcia i spowodować pojawienie się lepszych okoliczności"71. Depesza Viscontiego z 29 lipca była kontynuacją i w pewnej mierze wyjaśnieniem niepokojących doniesień zawartych w liście sprzed czterech tygodni. 1 lipca 1767 r. Visconti wyraził zaniepokojenie postawą króla, o którego dobrej wierze był dotąd przekonany:

Oby Bóg mi pozwolił czytać w sercu króla, żebym mógł pozbyć się kilku oznak niepokoju, jakie zrodziły się w mojej duszy, bym mógł ostatecznie zapewnić Waszą Eminencję o prawości jego zamysłów i szczerości jego obietnic, [wreszcie] o stałości jego wiary pośród tej strasznej burzy, która niszczy Polskę. Wasza Eminencja dobrze wie, że wielokrotnie zdarzało mi się analizować [ów] problem tak wielkiej wagi i delikatności, zwłaszcza w depeszy z 3 czerwca, i że liczne obserwacje potwierdzone wiarygodnymi domysłami i pozytywnymi dokumentami skłoniły mnie zasadniczo do uznania

pretensioni sì dei malcontenti, che dei Dissidenti'. Le pretensioni dei malcontenti sono di abrogare tutte le leggi nuove passate nell'ultima dieta, e qualcuno dei più arditi le ha spinte perfino a volere la detronizzazione del Re. In quanto all'abrogazione delle suddette leggi, tantum abest, che il Re abbia preso il partito di lasciarla correre, che ha fatto, e sta facendo tutti i sforzi per tenerla in piedi, pronto a secondare le pretensioni dei Dissidenti per mantenere questo punto. Dunque il Re cammina d'accordo in qualità d'agente colla Moscovia, che è diametralmente il contrario di quanto buonamente ha avanzato il mio Antecessore, e con questo sillogismo darò fine ai miei numeri”, A.M. Durini do L.M. Torrigianiego, Warszawa, 16 IX 1767, ASV, Segr. Stato Polonia 280, k. 205 (por. AD, t. 1, s. 17-20; ANP 52/1, N. 83). Fragmentu brak u Theinera.

${ }^{71}$ „L'incremento di zelo e coraggio che V.E. mi inculca in questa occasione, non è che giustissimo; bensì nascendo tutto giorno delle variazioni singolari, credo grandemente opportuno andar tuttavia operando con più e meno forza, secondo le circostanze appunto, per non troncare affatto ogni filo di speranza, che possa condurre a un discreto disimpegno, e far risorgere delle combinazioni migliori", A.E. Visconti do L.M. Torrigianiego, Warszawa, 29 VII 1767, ASV, Segr. Stato Polonia 280, k. 144v. Fragmentu brak u Theinera. 
dobrej wiary króla, mimo częstego plotkowania [na jego temat] zarówno wśród bliskich, jak i dalekich. Ale niektóre szczegóły nie przestają budzić we mnie najżywszego niepokoju. Powiedziano mi, że na nadchodzącym sejmie zostanie odczytane autentyczne pismo, które pozwoli przekonać się namacalnie o obietnicy wprowadzenia w Polsce wolności sumienia, danej carycy przez króla. Niektórzy mówią, że książę Czartoryski, wielki kanclerz litewski, stwierdził, że przyznanie praw dysydentom w Polsce jest niczym mniej, jak pretium coronae. Poza tym wielu zgadza się co do twierdzenia, że król na mocy sekretnego paktu z carycą postanowił nie przeszkadzać narodowi, ogarniętemu dziś fanatyzmem zawiązywania konfederacji. Nie brakuje tych, którzy zapewniają o rozmaitych tajnych i nocnych naradach króla i Repnina oraz starosty Brzostowskiego, marszałka konfederacji litewskiej, który w sekrecie przebywał w Warszawie przez dwa tygodnie. Wyznaję, że król ma nieskończenie wielu wrogów zdecydowanych oczerniać go w każdy możliwy sposób; ale z drugiej strony nie czuję się na siłach zlekceważyć tych poważnych podejrzeń i zbyć pewne oskarżenia, które choć bardzo trudne do rzetelnego potwierdzenia, są jednak dobrze uargumentowane i niepozbawione cech prawdopodobieństwa ${ }^{72}$.

72 „Piacesse pure a Dio, che legger potessi nel cuor del Re, per dileguare dall'animo mio qualunque nuvola di timore, ed esser in grado di assicurar decisivamente V.E. sull'integrità delle sue mire e la sincerità dei suoi voti, la fermezza della sua Religione in mezzo questo gravissimo turbine, che desola la Polonia. Ben sa l'E.V. che più volte mi è accaduto di dover chiamare ad esame un problema di tanta importanza e delicatezza, e segnatamente sotto li 3. Giugno, e che varie osservazioni sostenute da congetture plausibili e da documenti favorevoli, mi hanno per lo più disposto a credere il Re di buona fede, malgrado i frequenti cicaleggii si de' lontani che de' vicini. Ma certe particolarità a questi giorni mi sono giunte all' orecchio non lasciano di cagionarmi la più viva inquietudine. Mi è stato detto che uno scritto autentico, da leggersi nella prossima dieta straordinaria, farà toccar con mano l'impegno contratto dal Re colla Czarina di introdurre in Polonia la libertà di coscienza. Pretende taluno che il principe Czartoryski gran-cancelliere di Lituania si sia spiegato, che il ristabilimento dei Dissidenti in Polonia non era meno che pretium Coronae. Combinano poi moltissimi nell' asserire, che lo stesso Re abbia un patto segreto colla Sovrana di Russia di lasciar correre senza verun ostacolo l'odierno fanatismo della nazione a confederarsi. Né manca chi assicuri avere S.M. tenute varie conferenze clandestine in tempo di notte avanzata col principe Repnin, e collo starosta Brzostowski maresciallo della confederazione di Lituania, che ha soggiornato occultamente in Varsavia per due settimane. Confesso che il Re ha infiniti nemici congiurati a denigrarlo in ogni maniera; ma per altro io non mi sento forza che basti ad escludere i miei violenti sospetti e sprezzar certe accuse, le quali quantunque difficilissime da purificarsi con vero criterio, sono però bene circostanziate e munite di molti gradi di verisimiglianza", A.E. Visconti do L.M. Torrigianiego, Warszawa, 1 VII 1767, ASV, Segr. Stato Polonia 280, k. 122r.-123r. Theiner przepisał list poczynając od słów „Ben sa l'E.V. ...”. Zob. s. 215. Por. nader lakoniczne odniesienie do tego listu u E. Dudy, op. cit., s. 150. Autor nie cytuje uzupełniającej ten wywód depeszy Viscontiego z 29 lipca $1767 \mathrm{r}$. 
Dopiero w obliczu powyższych refleksji można zrozumieć cytowaną przez Duriniego opinię Viscontiego o królu z 29 lipca 1767 r., którą także warto przytoczyć w całości:

Ufam, że najbardziej poufną drogą, którą uważam za wiarygodną, zdołałem wreszcie zweryfikować prawdziwe nastawienie króla w obecnych warunkach. Krótko mówiąc: twierdzi się, że aby nie paść ofiarą Moskwy, po długich konsultacjach podjął trudną decyzję o ustąpieniu we wszystkim zarówno opozycji, jak i dysydentom. Nie oznacza to, że działa w charakterze agenta; jego sytuacja wymaga jedynie, by się nie opierał i cierpliwie znosił to, co wymusza Moskwa. W ten sposób spada mi zasłona z oczu i tłumaczy się zagadka długich i częstych rozmów króla z księciem Repninem, ponieważ wiem, że Jego Królewskiej Mości zależy na stopniowym odkrywaniu intencji Rosji co do Polski i osiąganiu mniejszego zła dzięki przyjaźni z ambasadorem ${ }^{73}$.

Powyższe słowa wydają się świadczyć o pewnym stopniu wzajemnego zrozumienia, które zaistniało pomiędzy Stanisławem Augustem i nuncjuszem Viscontim. Król nawet rozpoczął konsultacje w sprawie możliwości przedłużenia pobytu Viscontiego w Warszawie, na czas nadchodzącego sejmu, choćby w charakterze doradcy nowego nuncjusza Duriniego. Ustępujący dyplomata wyperswadował jednak władcy ów pomysł, zatem do złożenia oficjalnej propozycji nie doszło ${ }^{74}$.

Swoistą kontynuację stylu działania Viscontiego mogła teoretycznie zapewnić omówiona wyżej Instrukcja sekretariatu stanu dla nowego nuncjusza, która w dużej mierze czerpała z doświadczeń ustępującego dyplomaty. Widać w niej nieustanną dialektykę stanowczości i rozwagi, wynikającą z oceny krytycznej sytuacji Rzeczypospolitej. Nie sposób stwierdzić wprost zależności między treścią Instrukcji a sugestiami zawartymi w depeszach Viscontiego - wymagałoby to ewentualnych

73 „Per segretissimo canale che credo autentico la lusingo di aver potuto finalmente verificare le positive disposizioni del Re nel presente stato di cose. In poche parole, per non cadere egli stesso vittima della Moscovia, si asserisce, che dopo lunga consultazione abbia preso il duro partito di lasciar correr tutto riguardo alle pretensioni, si de' malcontenti che de' Dissidenti. Non è già che egli cammini d'accordo in qualità d'agente; ma la sua condizione è solo che non si opponga e vada pazientemente soffrendo quanto accade per parte della stessa Moscovia. Così mi viene a cadere il velo dagli occhi, e si spiega ancora la cifra de' lunghi e frequenti dialoghi del Re col Principe Repnin, giacché so che preme a S. Maestà di andar via via scoprendo le intenzioni della Russia rispetto alla Polonia, e profittando dell'amicizia dell'ambasciatore, esser trattato meno male", A.E. Visconti do L.M. Torrigianiego, Warszawa, 1 VII 1767, ASV, Segr. Stato Polonia 280, k. 114v.-145. Fragmentu brak u Theinera.

${ }^{74}$ A.E. Visconti do L.M. Torrigianiego, Warszawa, 8 VII 1767, ASV, Segr. Stato Polonia 280, k. 128-128v. Brak u Theinera. 
dalszych badań - lecz trudno się oprzeć przypuszczeniu, że taka zależność istnieje. Jeszcze bardziej uderzające są podobieństwa między Instrukcją a memoriałem opracowanym w początkach 1767 r. przez zaufanego audytora Viscontiego, ks. Paola Luigiego Silvę, następnie omawianym w czasie spotkań powołanej przez Klemensa XIII kongregacji do spraw polskich w Rzymie ${ }^{75}$.

Visconti miał do swego audytora ogromne zaufanie i rekomendował jego rady sekretarzowi stanu wiosną 1767 r., krótko po wyjeździe Silvy z Warszawy do Mediolanu ${ }^{76}$. Wobec tak pochlebnej opinii zalecenia tego ostatniego dla przyszłego nuncjusza w Polsce można traktować jako wyraz przekonań samego Viscontiego. Co ważne, są one pełne wezwań do nieustępliwości i odważnej obrony Kościoła, nawet za cenę osobistej ofiary. Trudno byłoby zatem podejrzewać u nuncjusza Viscontiego brak zrozumienia dla takiej radykalnej postawy, którą często utożsamia się dopiero z nuncjuszem Durinim i jego poparciem dla konfederacji barskiej. Jednak już w memoriale Silvy pojawia się obecna następnie w wielu miejscach Instrukcji zachęta do dyplomatycznej ostrożności, a nawet zgody na nieuniknione ustępstwa, powtórzona dobitnie w cytowanej wyżej depeszy abpa Viscontiego z 29 lipca.

W kurii rzymskiej rozumiano tego rodzaju dylematy, co widać najlepiej w kontekście wzmiankowanej już nominacji prymasowskiej ks. Podoskiego. Jak wspomniano wyżej, w swoim czasie nuncjusz Durini skrytykował Viscontiego także za brak ostrzeżeń co do tej kandydatury. W rzeczywistości ostrzeżenia takie w depeszach Viscontiego są obecne od pierwszej informacji o śmierci prymasa Łubieńskiego ${ }^{77}$. Stolica Apostolska była poinformowana przez Viscontiego zarówno o niegodności kandydata, jak i o niemożności skutecznego przeciwdziałania naciskom Rosji, która używała wobec króla gróźb i zastraszania. Zapytany przez Stanisława Augusta o radę w sprawie możliwej akceptacji otwarcie niegodnego kandydata przez papieża, nuncjusz stanowczo odradził mu nominację Podoskiego, przewidując także konsternację i opór Stolicy Apostolskiej. Przemoc Katarzyny II i Repnina zwyciężyła jednak najpierw

${ }^{75}$ Memoria del Sig. Ab. Paolo Luigi Silva uditore della nunziatura di Varsavia, esaminata nella Congregazione dei 4 giugno 1767, ASV, Segr. Stato Polonia 279 k. 22-34. Por. E. Duda, op. cit., s. 157-159. Transkrypcja całego memoriału tamże, s. 200-206. Por. J.T. Łukowski, op. cit., s. 83-84. W. Kęder, Stolica Apostolska, s. 212-216 omawia prace kongregacji, lecz nie wspomina o Silvie.

76 A.E. Visconti do L.M. Torrigianiego, Warszawa, 15 IV 1767, ASV, Segr. Stato Polonia 276, k. 201-202v. Fragmentu brak u Theinera.

77 A.E. Visconti do L.M. Torrigianiego, Warszawa, 24 VI 1767, ASV, Segr. Stato Polonia 280, k. 117-120 (por. Theiner, s. 214-215). 
w Warszawie ${ }^{78}$, a następnie i w Rzymie, mimo licznych dysput nad Podoskim w gronie kardynałów zajmujących się sprawami polskimi ${ }^{79}$. Arcybiskup Visconti, świadom sytuacji bez wyjścia, w jakiej znalazł się król, cały czas stanowczo odradzał kandydaturę Podoskiego, dodając dyplomatyczne: ,jeśli będzie to moźliwe” („se sarà possibile”) ${ }^{80}$.

Tego rodzaju minimalnej nawet ustępliwości brak w relacjach abpa Duriniego, który pod koniec 1767 r. w pełnym metafor prywatnym liście nawet oskarżył Viscontiego o zaprzedanie się dworowi i przekazywanie półprawd ${ }^{81}$. Król w relacjach Duriniego nie mógł liczyć na pochlebstwa $\mathrm{w}$ jednej z depesz z omawianego okresu został przedstawiony jako zwykły tchórz, który kryje się we własnym pałacu na myśl o ryzyku spotkania się twarzą w twarz z biskupem Sołtykiem ${ }^{82}$. Cytując Stanisława Augusta, wzywającego biskupów do zgody na ustępstwa wobec dysydentów z myślą o ocaleniu ojczyzny i o własnym bezpieczeństwie (po tym, jak Repnin zagroził już bpowi Sołtykowi zsyłką na Syberię), nuncjusz nie skomentował argumentów króla, lecz pochwalił odpowiedź biskupa przemyskiego: „Lepiej z religią na Syberii niż w Polsce bez religii”, choć podejrzewał, że może ona być pustą deklaracją obliczoną na wywołanie efektu ${ }^{83}$.

78 A.E. Visconti do L.M. Torrigianiego, Warszawa, 24 VI 1767, ASV, Segr. Stato Polonia 280, k. 117-v (także u Theinera, s. 214-215).

${ }^{79}$ Fogli delle Congregazioni particolari tenuti in Roma negli anni 1767 e 1768 e altre memorie spettanti agli affari di Polonia, ASV 279, passim. Por. E. Rostworowski, op. cit., s. 152-153. Por. W. Kęder, Stolica Apostolska, s. 213-215.

80 „Io per altro, sebbene minacciato implicitamente io medesimo dall'altro biglietto, non tralascerò d'insistere per fino all'ultimo a tenore del mio ministero per distogliere Sua Maestà da un passo si pernicioso, se sarà possibile”, A.E. Visconti do L.M. Torrigianiego, Warszawa, 24 VI 1767, ASV, Segr. Stato Polonia 280, k. 119v. Ten interesujący fragment listu Theiner opuścił w swej edycji.

81 „Mi giova sperare che i miei Dispacci non anderanno nelle zanne di lico. Di costà mi si promette che sono tenuti in perfetto segreto. Io scrivo alla Lombarda e tondo tondo, non a mezza bocca, come il mio degno antecessore, che era più degli abdolomini lici, e liberti, che della verità", A.M. Durini do Finaliego, Warszawa, 16 XII 1767, AD, t. 1, s. 108. Listu tego brak w edycji ANP 52/1.

82 A.M. Durini do L.M. Torrigianiego, Warszawa, 30 IX 1767, ASV, Segr. Stato Polonia 280, k. 223 (por. AD, t. 1, s. 26-32; Theiner, s. 225; ANP 52/1, N. 100). Anegdotyczna wzmianka dotyczy spotkania z kilkoma biskupami, które król zorganizował w swych apartamentach. Anonsowany miał być biskup kujawski, lecz przez omyłkę nazwano go „krakowskim”, na co król miał rzucić się do ucieczki.

83 "«Meglio in Siberia con Religione, che in Polonia senza». Questa risposta non può essere più bella, ma l'uomo non la pensa forse come le dice, e ha così risposto per gettare polvere agli occhi degli altri due Vescovi", A.M. Durini do L.M. Torrigianiego, Warszawa, 30 IX 1767, ASV, Segr. Stato Polonia 280, k. 223v.-224 (także u Theinera, s. 225). Król zaś - według pozostawionej bez komentarza relacji nuncjusza - nakłaniał biskupów do ustępstw w sprawach religijnych i do akcesu do konfederacji na warunkach Repnina, 
Po wręczeniu królowi na początku października papieskich brewe $\mathrm{z}$ apelem o obronę Kościoła podczas bliskiego już sejmu, gdy Stanisław August w odpowiedzi zadeklarował, iż gorąco modli się do Boga o mądrość i odwagę w postępowaniu, choć okoliczności, w jakich kraj się znajduje, domagają się raczej cudu Bożej Opatrzności, abp Durini stwierdził: „nie byłbym tak pewny, że modlił się tak gorliwie do Boga, ponieważ w Warszawie powszechnie się sądzi, iż przez całe życie nie odmówił nawet jednego Ojcze nasz, i ogólnie wiadomo, że Poniatowscy, ilu ich było, są niewierzący" ${ }^{4}$. Zdaniem nuncjusza indyferentyzm był cechą dworu i im bliżej Warszawy, tym bardziej kraj był nim zarażony ${ }^{85}$.

Antytezą bezbożnego, tchórzliwego i zaprzedanego Moskwie króla, byli w opinii Duriniego nieliczni pobożni i gorliwi patrioci. Relacjonując słowa i postępowanie Karola Stanisława Radziwiłła, który w tym czasie często deklarował gotowość poświęcenia się dla sprawy religii, nuncjusz wykrzyknął: „Dałby Bóg, aby biskupi byli ożywieni duchem i gorliwością księcia Radziwiłła" ${ }^{86}$. Pomimo rosyjskich represji, których ofiarą padali już przeciwnicy Repnina, jak Feliks Czacki i Franciszek Kożuchowski, nuncjusza cieszyli Polacy gotowi hardo odpowiadać na groźby ambasadora. Durini zrelacjonował postawę jednego z konsyliarzy konfederacji radomskiej, Józefa Pułaskiego, który opierał się pomysłowi Repnina oficjalnego zaproszenia dysydentów do konfederacji. Gdy ambasador zagroził sprowadzeniem do Warszawy 15 tys. żołnierzy, Pułaski „odpowiedział odważnie, że nawet 100 tysięcy nie wystarczy do zniewolenia prawdziwie wolnych i katolickich dusz" ${ }^{27}$.

bez czego „możemy stracić i religię, i ojczyznę”: „Signori miei, la Patria è in un estremo pericolo, pensiamo a salvarla, per salvarla converrà accordare non poco ai Dissidenti; se non si accorda, perderemo e la Patria, e la Religione; non mancheranno le occasioni in avvenire per rifare la Religione del discapito, che ora forza è che soffra: prego dunque loro Signori di non più difficoltare il loro accesso alla confederazione e di piegarsi ai desideri del Principe Repnin", A.M. Durini do L.M. Torrigianiego, Warszawa, 30 IX 1767, ASV, Segr. Stato Polonia 280, k. 223 (także u Theinera, s. 225; ANP 52/1, N. 100).

84 „Io non ci giurerei ch'egli abbia pregato Dio così ardentemente, poiché in Varsavia opinione comune è che non abbia mai detto in vita sua neppure il Pater noster, ed è notorio, che i Poniatowski quanti sono non hanno Religione", A.M. Durini do L.M. Torrigianiego, Warszawa, 5 X 1767, ASV, Segr. Stato Polonia 280, k. 228v.-229 (por. AD, t. 1, s. 36-41; Theiner, s. 228; ANP 52/1, N. 118). Por. E. Duda, op. cit., s. 164.

${ }^{85}$ A.M. Durini do L.M. Torrigianiego, Warszawa, 9 IX 1767, ASV, Segr. Stato Polonia 280, k. 192v. (por. AD, t. 1, s. 15-17; Theiner, s. 223; ANP 52/1, N. 72).

${ }^{86}$ „Volesse Dio, che i vescovi fossero animati dallo spirito, e zelo del Principe di Radzievil", A.M. Durini do L.M. Torrigianiego, Warszawa, 9 IX 1767, ASV, Segr. Stato Polonia 280, k. 193. Fragment opuszczony u Theinera. Por. ANP 52/1, N. 72.

87 „rispose coraggiosamente, che per soggiogare animi liberi, e veramente Cattolici non basteranno ne anche 100 mila”, A.M. Durini do L.M. Torrigianiego, Warszawa, 30 IX 
Najważniejszą postacią opozycji był bp Kajetan Sołtyk i nuncjusz starał się scharakteryzować go szczerze: „Nie chcę twierdzić, że odwaga biskupa krakowskiego wynika wyłącznie z gorliwości [religijnej]. Uważam, że jest w nim domieszka dążeń, by zniweczyć nowe ustawy przyjęte na ostatnim sejmie, które rzeczywiście przyznają zbyt wiele władzy królewskiej, ale ostatecznie tylko on swymi poczynaniami stanowi zaporę dla przesadnych pretensji dysydentów, a oni, widząc to dobrze, wytaczają przeciw niemu wszystkie swoje działa"88. Nie sposób przytoczyć wszystkich słów świadczących w relacjach Duriniego o odważnej i nieprzejednanej postawie biskupa (np. na sugestię, by udał chorobę i nie pojawiał się na sejmie, odpowiedział: „gdybym nawet widział na swej szyi sznur, wziąłbym udział w sejmie, by swój ostatni oddech oddać dla sprawy religii i wolności" ${ }^{89}$ ). Do kulminacyjnego wydarzenia doszło na otwarciu obrad sejmu 1767 r., gdy sprzeciwiając się powołaniu komisji do rozpatrzenia postulatów dysydentów, Sołtyk, wedle relacji nuncjusza, odwrócił się w stronę króla i powiedział: „Oto nadszedł czas, Panie, [--], żeby potwierdzić czynem obietnice dane słowem na ostatnim sejmie, tj. utracić królestwo i życie dla religii. [--] Wszyscy biskupi zaklaskali, żeby dać do zrozumienia, że mają takie samo nastawienie. Tylko prymas pozostał mutus ut piscis, i to lepiej, gdyż gdyby otworzył usta, Bóg wie, jak by przemówił"90.

Po tej pierwszej sesji, gdy z równą gorliwością przemówił także Wacław Rzewuski, „niezrównany wojewoda krakowski”, Durini miał poczucie zwycięstwa dobrej sprawy, radował się, że królowi i jego zwolennikom

1767, ASV, Segr. Stato Polonia 280, k. 220v.-221 (por. AD, t. 1, s. 26-32; Theiner, s. 224; ANP 52/1, N. 100).

88 „Io non voglio asserire a V.E. che il coraggio del Vescovo di Cracovia sia tutto zelo. Voglio credere, che sia misto di uno spirito, che tende a distruggere le nuove leggi passate nell'ultima Dieta, e che veramente danno troppo all'autorità Regia, ma a buon conto egli è il solo, che co' suoi maneggi fa argine alle smisurate pretensioni dei Dissidenti, ed essi, che ben lo vedono, dirizzano tutte le loro macchine contro di lui", A.M. Durini do L.M. Torrigianiego, Warszawa, 16 IX 1767, ASV, Segr. Stato Polonia 280, k. 202 (por. AD, t. 1, s. 17-20; Theiner, s. 223; ANP 52/1, N. 83).

89 "Quand'anche mi vedessi colla corda alla gola, mi farei portare in Dieta per spendervi l'ultimo mio fiato in vantaggio della Religione e della libertà", A.M. Durini do L.M. Torrigianiego, Warszawa, 16 IX 1767, ASV, Segr. Stato Polonia 280, k. 202v. (fragmentu brak $u$ Theinera).

90 „Ecco il tempo, sire [--], di confermare coi fatti quello, che in parole avete promesso nell'ultima Dieta, cioè di perdere e Regno, e vita per la Religione. [--] Tutti i vescovi applaudirono per dare a conoscere, che tutti erano nell'istessa disposizione. Il solo Primate rimase mutus ut piscis, ed è stato meglio, perché se apriva la bocca, Dio sa, come avrebbe parlato", A.M. Durini do L.M. Torrigianiego, Warszawa, 5 X 1767, ASV, Segr. Stato Polonia 280, k. 230v. (por. AD, t. 1, s. 36-41; Theiner, s. 229; ANP 52/1, N. 118). Por. E. Duda, op. cit., s. 169. 
przytarto nosa, i dawał do zrozumienia, że jest to po części owocem jego starań o rozbudzenie gorliwości narodu: „wiem, że król powiedział, iż to nuncjusz zainspirował te wystąpienia. Mam jednak satysfakcję, że prawi ludzie przyznają mi w tej sprawie rację"11. Ta budząca optymizm atmosfera trwała kilka dni. Relacjonując sesję 12 października, podczas której intencjom Stanisława Augusta skutecznie zaprzeczył bp Sołtyk, nuncjusz znów nie szczędził gorzkich słów władcy:

Podczas całego sejmu zauważono zły nastrój króla, a pewna osoba powiedziała mi, że nie przemawiał z właściwą sobie swadą; co w ogóle mnie nie dziwi, ponieważ rola, którą odgrywa w tym spektaklu, jest żenująca: nie może się opowiedzieć przeciw dysydentom w obecności Repnina, po przysiędze, jaką złożył imperatorowej, że będzie ich popierał; z drugiej strony nie ma odwagi przemawiać bezwstydnie przeciw katolikom, widząc ich gorliwość i jedność, a zatem znajduje się między młotem a kowadłem ${ }^{92}$.

Gdy ostatecznie doszło do aresztowania przez Repnina bpów Sołtyka i Załuskiego oraz hetmana Rzewuskiego z synem (nocą z 13 na 14 października), opozycja, a za nią nuncjusz, stwierdziła jednoznacznie, że „wszystko to uczyniono w porozumieniu z królem" ${ }^{93}$. Zastraszenie posłów, lęk przed równie gwałtownym usunięciem z Warszawy nuncjusza oraz rosnąca arogancja Repnina skłoniły abpa Duriniego do wyznania: „Krótko mówiąc, wszystko jest stracone” ${ }^{94}$. W tej samej depe-

91 „So che il Re ha detto, che il Nunzio aveva fatto questo colpo di testa sua. Dai buoni però ho il contento di sentirmi applaudito in questo passo", A.M. Durini do L.M. Torrigianiego, Warszawa, 5 X 1767, ASV, Segr. Stato Polonia 280, k. 231v. (por. AD, t. 1, s. 36-41; Theiner, s. 229; ANP 52/1, N. 118, z usterką w transkrypcji). Por. E. Duda, op. cit., s. 169-171.

92 „Fu osservato il mal umore del Re durante tutta la Dieta, e qualch'uno mi ha detto, che non ha parlato colla sua solita felicità; il che per altro non mi sorprende, poiché la parte, che fa in questa scena è imbarazzante: non può egli dichiararsi contro i Dissidenti in faccia al Repnin, dopo il giuramento fatto all'Imperatrice di favorirli; dall'altro canto non ardisce di parlare sfacciatamente contro i Cattolici, vedendo il zelo e l'unione dei medesimi, e perciò si trova tra l'incudine e il martello", A.M. Durini do L.M. Torrigianiego, Warszawa, 12 X 1767, ASV, Segr. Stato Polonia 280, k. 255v. (por. AD, t. 1, s. 48-52; Theiner, s. 233; ANP 52/1, N. 141, z usterką w transkrypcji). Por. E. Duda, op. cit., s. 175.

93 "Si tiene per fermo che tutto questo siasi fatto di concerto col Re”. A.M. Durini do L.M. Torrigianiego, Warszawa, 14 X 1767, ASV, Segr. Stato Polonia 280, k. 259v. (por. AD, t. 1, s. 51-52; Theiner, s. 233; ANP 52/1, N. 142). Por. E. Duda, op. cit., s. 177, z komentarzem: „Au sujet du Roi les soupçons de Durini ne tombaient jamais à faux”.

94 „In due parole, tutto è perduto”, A.M. Durini do L.M. Torrigianiego, Warszawa, 19 X 1767, ASV, Segr. Stato Polonia 280, k. 274v. (por. AD, t. 1, s. 55-56; Theiner, s. 234; ANP 52/1, N. 151). Por. E. Duda, op. cit., s. 178. 
szy nuncjusz po raz pierwszy zareagował na zarzuty, które miały zostać skierowane przeciw niemu do Rzymu, podkreślając, że we wszystkich swych działaniach wypełniał wiernie instrukcje otrzymane od przełożonych: „Dowiedziałem się, że król wysyła do Rzymu byłego prowincjała kapucynów, aby usprawiedliwić się z zaistniałych wydarzeń, na które jakoby nie miał wpływu, a może także, aby poskarżyć się, że działałem $\mathrm{z}$ nadmiernym zapałem ["che io abbia usato troppo calore”]; co jest fałszem, ponieważ nie uczyniłem nic innego, jak tylko wypełniłem moje instrukcje i ostatnie wskazówki z Rzymu" ${ }^{95}$. Misja byłego prowincjała kapucynów ${ }^{96}$ dała okazję do zamanifestowania odmiennej koncepcji służby dyplomatycznej nuncjusza Duriniego i jego poprzednika, abpa Viscontiego. Wrogie nastawienie do królewskiego emisariusza, wyrażone w depeszy Duriniego, kontrastuje z opinią przesłaną do Rzymu przez audytora abpa Viscontiego, ks. Silvę:

Powinien dotrzeć do Rzymu około 20 grudnia o. Antonin Przedwojewski, były prowincjał kapucynów, krewny prymasa. Zakonnik ów był zaufanym człowiekiem biskupa krakowskiego i otrzymał od Repnina polecenie ostrzeżenia go, żeby postępował rozważniej, inaczej zostanie aresztowany. Zakonnik wypełnił poleconą mu misję, a biskup w odpowiedzi okazał się bardziej senatorem, niż biskupem. [--] Jeśli Wasza Eminencja zechce z nim porozmawiać o sprawach polskich, publicznych i prywatnych, może po niego posłać. Dufam, że chętnie się stawi, ponieważ wstępnie mu o takiej możliwości napomknąłem. Zakonnik ów jest także protegowanym króla. Okazaliśmy mu w Wiedniu wszelkie zainteresowanie, nie tylko z uwagi na jego powiązania, ale także trzymając się zasady, że należy pozyskiwać sobie tych, którzy mogą wpływać na zły lub dobry obrót spraw ${ }^{97}$.

95 „Sento che il Re spedisca a Roma l'Exprovinciale di questi Cappuccini per giustificarsi di quanto occorre come di cosa non sua, e forse anche per lagnarsi, che io abbia usato troppo calore; il che è falso, non avendo io fatto altro, che eseguire le mie Istruzioni, e gli ultimi oracoli di Roma", A.M. Durini do L.M. Torrigianiego, Warszawa, 19 X 1767, ASV, Segr. Stato Polonia 280, k. 274v.-275 (por. AD, t. 1, s. 55-56; Theiner, s. 235; ANP 52/1, N. 151).

${ }^{96}$ Biogram Przedwojewskiego w PSB nie wspomina o tej podróży, zob. K. Gadacz, Przedwojewski Kornel, w zakonie Antonin, w: PSB, t. 28, Wrocław 1984-1985, s. 712-714. Podkreślony został natomiast bliski związek kapucyna z prymasem Podoskim, co „kompromitowało go w opinii publicznej" (ibidem, s. 713). ANP 52/1, N. 151 błędnie identyfikuje kapucyna jako Adama Dunina Wąsowicza.

97 „Dovrebbe arrivare a Roma circa il giorno 20 dell'entrante mese il P. Antonino Predwozeiwski exprovinciale Capuccino, Parente di Mons. Primate. Era questo Religioso Confidente del Vescovo di Cracovia, ed ebbe incombenza dal Principe Repnin di avvertirlo, che si regolasse con maggiore prudenza, altrimenti l'avrebbe fatto arrestare, adempì il Religioso la Commissione, ed il Vescovo nella risposta si mostrò senatore più 
Arcybiskup Durini, świadom już czynionych przeciw niemu kroków dworu warszawskiego, w depeszach do końca 1767 r. kilkakrotnie przekazał Stolicy Apostolskiej nader negatywny obraz polskiego władcy, odpierając przy okazji zarzuty dotyczące własnego sposobu działania jako papieskiego reprezentanta. Według nuncjusza Stanisław August od „początku panowania dążył do despotyzmu”, przymilając się Moskwie w sprawie dysydentów i pozbawiając Rzeczpospolitą władzy nad skarbem i wojskiem (na sejmie 1766 r.). W efekcie króla wspierała armia rosyjska, a republikanie zostali pozbawieni możliwości zorganizowania obrony. Nuncjusz dodawał: „Król spogląda na mnie złym okiem i nie jest w stanie znieść faktu, że wypełniam swój obowiązek, zamiast tego uważa gorliwość za fanatyzm. Nie jest nieprawdopodobne, że skieruje do Waszej Eminencji jakieś zażalenia przeciwko mnie, jakobym w tej sprawie nadmiernie dolewał oliwy do ognia. Ja zaś nie jestem świadom, bym uczynił coś innego, poza prezentacją papieskich brewe oraz zagrzewaniem biskupów, by byli niewzruszeni"98. Zdaniem Duriniego, przychylność Stanisława Augusta dla dysydentów miała długą historię - jeszcze w latach panowania Augusta III należał do grona szlachty otwarcie im sprzyjającego ${ }^{99}$.

che Vescovo. [--] S'ella è curiosa di parlargli ed interrogarlo delle cose di Polonia pubbliche, e private, lo mandi a ricercare, mentre mi lusingo che verrà volontieri, avendogliene io di già fatto qualche motto. Lo stesso Religioso è protetto anche da S. Maestà. Noi gli abbiamo usato in Vienna ogni attenzione non solo per le di lui aderenze, ma anche condotti dal principio, che conviene coltivare chi può influire nel bene e nel male", P.L. Silva do L.M. Torrigianiego, Wiedeń, 30 XI 1767, ASV, Segr. Stato Polonia 280, k. 343. Por. ANP 52/1, N. 205, z usterkami w transkrypcji.

${ }^{98} \mathrm{~W}$ poniższych przypisach cytuję dłuższe fragmenty oryginalnych depesz, w tekście jedynie streszczonych: „Il Re fino dal bel principio della sua elezione ha mirato al Dispotismo; per giungervi ha promesso da un lato alla Moscovia di favorire i Dissidenti, e dall'altro ha spogliato la Repubblica dell'amministrazione del Tesoro, e del comando delle armi, facendo trasferire a se l'una e l'altro per le leggi passate nella Dieta dell'anno scorso; sicché la Repubblica non ha più con che opporsi al Dispotismo del Re sostenuto dalle armi Russe, e per tornare in piedi la libertà, e la Religione in questo Regno non vuole essere meno, che una mutazione nel sistema politico di Europa; Dio lo faccia! quel Dio, in cuius manu corda Regum sunt. 1ntanto io preveggo un Ministero si disgustoso, che mi augurerei d'esserne a mille miglia. Mi guarda il Re di mal occhio, e non può digerire, che io abbia fatto il mio dovere, interpretando egli il zelo per fanatismo. Non è inverisimile, che porti qualche doglianza contro di me a V.E., come se io avessi usato troppo calore in questo negozio: oltre la presentazione dei Brevi io non so di avere fatto altro, se non che animare i Vescovi a stare saldi, questo è dovere del Nunzio, tanto più indispensabile, che mi è stato ingiunto nelle Istruzioni, e nelle lettere consecutive", A.M. Durini do L.M. Torrigianiego, 21 X 1767, ASV, Segr. Stato Polonia 280, k. 280-280v. (por. AD, t. 1, s. 56-58; Theiner, s. 235; ANP 52/1, N. 154). Por. E. Duda, op. cit., s. 179.

99 „Prima della morte di Augusto III i Moscoviti alleati del Re di Prussia avevano quartiere in Polonia, e si sa di certo, che vi si fermarono ad insinuazione dei Czartoriski 
Do oskarżeń natury politycznej nuncjusz dodał zarzut pozorowania gorliwości religijnej i hipokryzji. W czasie sejmu 1766 r. król okazał te cechy najpierw sprzeciwiając się podpisaniu ustawy w sprawie religii katolickiej, proponowanej przez bpa Sołtyka, gdy zaś ta została przez posłów przyjęta, wypowiedział się o niej tak pozytywnie, że „wydał się szczery tym, którzy myślą powierzchownie, ale ci, którzy docierają do sedna, dobrze zauważyli, że wynikało to z okoliczności, a nie z gorliwości", następnie zaś tłumaczył się przed Repninem ze swej maskarady ${ }^{100}$. W przededniu sejmu 1767 r., gdy Repnin zdołał już wymusić akces do konfederacji radomskiej nawet na tak niezłomnych hierarchach, jak bp krakowski, nuncjusz przewidywał „najgorsze nieszczęścia dla Kościoła”. Jednocześnie odmawiał dobrej wiary królowi, kwestionując opinie Viscontiego ${ }^{101}$. Po uwięzieniu senatorów, prośbę króla o ich uwolnienie

per essere pronti a secondare i loro tentativi. Appena morto il Re Augusto, cominciarono subito i Dissidenti ad alzare la testa, ed a stimolare in alcune terre la nobiltà, perché favorisse il loro disegno. Non mancò fra i Cattolici chi mostrossi loro amico: lo stesso Re presente fu prima vociferato Fautore dei Dissidenti, che Candidato al Trono", A.M. Durini do L.M. Torrigianiego [Origine della Confederazione Generale del Regno di Polonia e Granducato di Lituania nell'Anno 1767], 28 X 1767, ASV, Segr. Stato Polonia 280, k. 290v. (por. AD, t. 1, s. 59-64; Theiner, s. 236; ANP 52/1, N. 163).

100 „La Dieta si teneva sotto il vincolo dell'istessa Confederazione fatta nell'Interregno, e non mai sciolta. Perorava a favore dei Dissidenti l'ambasciatore di Moscovia, ed il Residente di Prussia, arringava a pro' de' Cattolici il Nunzio Apostolico. Bollivano ambe le parti. Volevano gli Ortodossi prima d'ogni altra cosa, che si sottoscrivesse la costituzione circa la Religione proposta dal Vescovo di Cracovia. Al che il Re co' suoi faceva forte ostacolo con suo disonore parendo così evidente Fautore degli Eretici. Malgrado le disdicevoli brighe del Re, e della Corte la vinsero gli Ortodossi, e fu sottoscritta la costituzione del Vescovo di Cracovia con tale impeto di zelo universale, che il Re stesso dopo avervi fatto contro si vide costretto di abbracciarla; per non caricar dell'odio pubblico, e vi arringò sopra con sì bene affettata eloquenza, che parve sincero a chi si ferma nella scorza delle cose, ma chi ne penetra il midollo ben si accorse, che il Re aveva più servito al tempo, che al zelo. Si sa, che di questa sua maschera si giustificasse col Repnin, dicendo, che non poteva pigliarsela solo contro tutta la Nazione, e che meglio assodato sul Trono avrebbe parlato diversamente", A.M. Durini do L.M. Torrigianiego [Origine della Confederazione Generale del Regno di Polonia e Granducato di Lituania nell'Anno 1767], 28 X 1767, ASV, Segr. Stato Polonia 280, k. 292v.-293 (por. AD, t. 1, s. 59-64; Theiner, s. 237; ANP 52/1, N. 163).

101 „Non è credibile lo spavento, che questo Ministro [Repnin] ha gettato in tutti gli animi, a tale, che il Vescovo di Cracovia, che ha sempre affettato intrepidezza, si mostra ora in tanta costernazione, che non più tardi di ieri sera mi ha detto, che converrà bere grosso, ed accettare la formola d'accesso proposta dall'Ambasciatore. Io non ho mancato di fargli coraggio, confortandolo a non dare passo, che possa riuscire dannoso alla Religione, ma non vi è forza di parole, che possa risorgere spiriti avviliti; e se Dio non vi mette la sua Santa Mano, preveggo le più funeste disavventure per la Religione. Mi duole di fare così sinistro prognostico, ma io non so parlare di mezza bocca, né chiamar 
uznał za „maskaradę zbyt oczywistą, ponieważ jest rzeczą wiadomą, że król był głównym sprawcą aresztowania” 102 . „Król jest główną przyczyną wszystkich nieszczęść Polski, a prymas jest jego głównym narzędziem", konkludował bez wątpliwości ${ }^{103}$.

$\mathrm{Na}$ nieograniczoną aprobatę abpa Duriniego mogli natomiast liczyć przedstawiciele opozycji, czego najwymowniejszym przykładem są opinie przekazywane do Rzymu o Radziwille. W tym samym czasie Silva pisał: „Co do osoby księcia Radziwiłła, wydaje mi się, że pozostał zawsze ten sam i łudził się, kto uważał inaczej. Czegokolwiek by nie mówił, jego postępowaniem kierowały wciąż te same zasady i te same osoby, a kto go zna, musi stwierdzić, że inaczej być nie mogło"104.

Opinia o nuncjuszu angażującym się zbyt jednostronnie w życie polityczne Rzeczypospolitej szybko zaczęła docierać poza granice kraju, a wraz z nią pojawiały się próby apologii jego niezłomnego postępowania w obronie praw Kościoła. Durini dwukrotnie dziękował Giuseppe Garampiemu za wyrazy uznania dla swej postawy ${ }^{105}$. Za drugim razem,

sospetti le certezze; e soprattutto non posso indurmi a credere, che il re sia di buona fede in tutto questo negozio, come lo ha creduto, e scritto il mio antecessore. Faccia Dio, che io m'inganni", A.M. Durini do L.M. Torrigianiego, Warszawa, 26 VIII 1767, ASV, Segr. Stato Polonia 280, k. 183-183v. (por. AD, t. 1, s. 10-12; Theiner, s. 220; ANP 52/1, N. 50). Por. E. Duda, op. cit., s. 151, 154.

102 „Il Sig. Psarski Residente qui [w Rosji] del nostro Re ha presentato un memoriale a nome dell'istesso Re per il rilascio dei Prigionieri, ma questa è una maschera troppo scoperta, poiché si sa, che il Re è stato il principale promotore dell'arresto", A.M. Durini do L.M. Torrigianiego [cytując depeszę kanonika Kołakowskiego (?) z Moskwy, adresowaną 17 XI do kanonika Olechowskiego], 12 XII 1767, ASV, Segr. Stato Polonia 280, k. 355-355v. (por. AD, t. 1, s. 105-107; ANP 52/1, N. 214; brak u Theinera).

103 „[P. Antonio] si è vantato, che va a Roma ad standum incaricato di alcuni affari del Re, e del Primate, di cui si dice, che sia parente. Quante bugie metterà egli in campo per inorpellare la loro condotta, e per denigrare il zelo dei vescovi di Cracovia e Kiovia! Quello che non dirà certamente sarà la verità, cioè che il Re è la principale cagione di tutte le calamità della Polonia, ed il Primate ne è il principale istrumento", A.M. Durini do L.M. Torrigianiego, 11 XI 1767, ASV, Segr. Stato Polonia 280, k. 305v.-305 (por. AD, t. 1, s. 68-72; Theiner, s. 240; ANP 52/1, N. 178).

104 „Circa la Persona del Principe Radziwill mi creda è sempre stato lo stesso, e si è ingannato chi ha creduto diversamente. Qualunque sia stata la di lui maniera di parlare, la di lui condotta è sempre stata regolata dallo stesso principio, e dalle stesse Persone, e chi conosce il Soggetto deve convenire, che non può essere altrimenti", P.L. Silva do L.M. Torrigianiego, Wiedeń, 30 XI 1767, ASV, Segr. Stato Polonia 280, k. 342v. Niestety, poza aluzjami Silva nie przekazuje w tej materii dalszych informacji. Por. ANP 52/1, N. 205.

105 A.M. Durini do G. Garampiego, Warszawa, 25 XI 1767, AD, t. 1, s. 85-86 oraz A.M. Durini do G. Garampiego, Warszawa, 9 XII 1767, AD, t. 1, s. 103-105. Brak transkrypcji czy choćby wzmianki o tych listach w ANP 52/1. Do pism Garampiego na tym etapie badań nie byłem w stanie dotrzeć. Jedynie drugi ze wskazanych listów Duriniego 
obok podziękowań, przekazał też szersze wytłumaczenie swych działań, co zdaje się świadczyć, że Garampi przekazał nuncjuszowi treść oskarżeń kierowanych pod jego adresem oraz dawał kilka rad co do konieczności poprawy jego relacji z dworem królewskim. Durini podkreślił, że obowiązki związane ze swym stanowiskiem wypełni wiernie, choćby miało go to kosztować wiele trudu i niechęci ludzkiej: „Spodobało się Ojcu Świętemu [obdarzyć wysoką godnością] najmniejszych, kierując niestety mnie do zaszczytnego zaangażowania. Nałożył na mnie swoje najświętsze dłonie, dlatego muszę uczynić wszystko, by stanąć na wysokości zadania i wypełnić wiernie obowiązki [--]; uczynię to [--] nawet za cenę przykrości, cierpień, doświadczenia niechęci, pocieszając się tym najświętszym zdaniem: si hominibus placerem, Christi servus non essem"106.

W tym samym liście nuncjusz stanowczo dementował pogłoski, jakoby zbytnio mieszał się do polityki („è falso, falsissimo, che io mi sia mescolato troppo nelle cose politiche") i podkreślał, że wielokrotnie deklarował wobec króla neutralność. Rzecz jasna miał do czynienia z osobami w politykę zaangażowanymi, lecz trudno jest oddzielić biskupa od jego godności senatorskiej - pisał - a on, jako nuncjusz, był zobowiązany do podtrzymywania gorliwości biskupów w sprawach religii i nie miał prawa „cenzurować ich zaangażowania politycznego”. Durini podejrzewał, że jednym ze źródeł negatywnych opinii o jego pracy jest królewski rezydent w Rzymie, Tommaso Antici, liczył jednak na zaufanie i poparcie sekretarza stanu ${ }^{107}$.

do Garampiego został uwzględniony w indeksie korespondencji Garampiego, zob. D. Vanysacker, The Garampi Correspondence. A Chronological List of the Private Correspondence of Cardinal Giuseppe Garampi (1741-1792), Leuven 1997. W tomie tym brak wzmianki o listach adresowanych przez Garampiego do Duriniego w omawianym okresie.

106 „È piaciuto a N.S. d'innalzare gli infimi, destinandomi in questo purtroppo illustre impiego. Egli mi ha imposto le sue santissime mani, la onde io debbo porre tutte le mie forze in dare buon conto di me, e in adempire fedelmente le obbligazioni del mio carico; il che farò sempre anche a costo di disgusti, travagli, e di vedermi guardato di mal occhio, consolandomi con quel detto santissimo: si hominibus placerem, Christi servus non essem", A.M. Durini do G. Garampiego, Warszawa, 9 XII 1767, AD, t. 1, s. 104. Brak w ANP 52/1. Na temat tej postawy Duriniego zob. też E. Duda, op. cit., s. 151.

107 „e siccome era mio preciso debito applaudire al loro zelo eroico per la Religione, così non mi era lecito erigermi in censore della loro condotta nelle materie Politiche, e dovevo contentarmi di protestare, come ho sempre fatto, che questa non era la mia messa: ma la Corte avrebbe voluto, che io disapprovassi in tutto e per tutto le procedure dei Zelanti, ed a questo prezzo metteva la sua amicizia, ed il buonviso. Sed non ego credulus illi - Questo è il mio gran delitto, e delitto che non si perdona nelle corti, come Ella ben sa, ad ogni modo conviene simulare, come Ella molto prudentemente mi consiglia, e far lieto viso a chi me lo fa arcigno", A.M. Durini do G. Garampiego, Warszawa, 9 XII 1767, AD, t. 1, s. 104-105. 
Niemal w tym samym czasie audytor nuncjusza Viscontiego, wcześniej w Warszawie, a obecnie w Wiedniu, znany już ks. Paolo Luigi Silva, przekazywał przeważające w stolicy cesarstwa negatywne opinie dotyczące Rzeczypospolitej - z jego aluzji wynika, że głównym celem krytyki była warszawska nuncjatura, choć tłumaczenie włoskiego oryginału w kilku miejscach nie poddaje się jednoznacznym interpretacjom. Zdaniem audytora, za niepotrzebne uznawano doprowadzenie do konfrontacji z Repninem i zamknięcie drogi do kompromisu bez podjęcia próby dyplomatycznego rozwiązania sporów. Te pejoratywne sądy osłabiały nawet wymowę papieskich interwencji na korzyść Polski:

Ekscelencjo, pośród wielu niekorzystnych uwarunkowań pojawia się i to, że wszyscy, dokładnie wszyscy, jakiegokolwiek stanu i pozycji, dobrzy i źli, w Polsce i w Wiedniu, są uprzedzeni do naszych polskich orędowników, a z tego, co się mówi, wynika, że nie ma szans na likwidację owego fatalnego uprzedzenia [--]. Jest rzeczą pewną, że Delegacja wyposażona w prerogatywy władzy ustawodawczej musi być uznana za szkodliwą, sam to podkreślałem jeszcze w Warszawie, stąd też byłoby pożądane uniknięcie jej powołania. Niepowodzenie w tej kwestii nie musiało jednak oznaczać porzucenia Kościoła, przeciwnie, tym bardziej należało mu służyć w czasie, gdy planowano [negocjować] większe lub mniejsze [ustępstwa]. Należało zatem, aby osoby najbardziej utalentowane, najodważniejsze i najgorliwsze pozostały na miejscu, aby zaangażować się w tak wyjątkowym czasie. Należało pozyskać przyjaźń, wiarę i zaufanie króla, prymasa i innych członków Delegacji, a nawet wroga, należało mieć kogoś, kto mógłby grzecznie, cierpliwie i wytrwale wykazywać wady niektórych ustępstw, i kto - bez narażania na szwank swej pozycji mógłby zaproponować projekt kompromisowy w odpowiedzi na przesadny plan dysydentów, który, nie wątpię, został Waszej Eminencji przekazany przez jego ekscelencję nuncjusza. Jeśli to wszystko okazałoby się na nic, wówczas gorliwi powinni na sejmie stawić ostry opór i dać się zawlec na Syberię, byle nie ratyfikować nieprawości. W takim wypadku i ja pragnąłbym ofiar, dla wzniesienia wiecznej pamiątki zastosowanej przemocy oraz nieważności praw, które zostałyby przeforsowane ${ }^{108}$.

108 „Mons. mio, fra le molte svantaggiose combinazioni abbiamo anche quella, che tutti e poi tutti, di qualunque stato e condizione, buoni e cattivi in Polonia, ed in Vienna sono prevenuti contro i nostri Campioni di Polonia, e per quanto si dica per distruggere questa pessima prevenzione tutto è inutile, mentre sono infiniti i monumenti di ogni genere, e d'ogni specie, ai quali si appoggia questa comune cattiva opinione. È certo, che la Commissione con la facoltà legislativa deve considerarsi come perniciosa, già me ne dichiarai, mentre ero costì, e però sarebbe stato desiderabile, che si fosse potuto evitarla, ma non potendosi evitare la commissione, non era da abbandonarsi la Religione, anzi era necessario assisterla più che mai nel tempo appunto, in cui si doveva discorrere del più, e del meno. Conveniva dunque, che le Persone dotate di maggiori 
Z powyższego wywodu zdaje się wynikać jedna konstatacja - nuncjuszowi Duriniemu nie można było zarzucić, iż przekroczył instrukcje Stolicy Apostolskiej co do gorliwej obrony katolicyzmu aż po ofiarę z własnej wolności i mienia. Do podobnych ofiar zachęcałby także jego poprzednik Visconti i jego audytor Silva. List Silvy dowodzi jednak, że nawet w kręgach kościelnych pojawiła się wątpliwość, czy nuncjusz Durini podjął jakąkolwiek próbę dyplomatycznego osiągnięcia mniejszego zła w materii dysydenckiej w Rzeczypospolitej, zanim doszło do ostrej konfrontacji opozycji z królem oraz radykalnej reakcji rosyjskiego ambasadora i usunięcia z sejmu przywódców opozycji.

Co więcej, na przełomie 1767 i 1768 r. zaczęto się obawiać, że Repnin rzeczywiście doprowadzi do likwidacji nuncjatury, co byłoby fatalnym dopełnieniem całkowitej porażki opozycji i abpa Duriniego w kwestii dysydenckiej. Późną jesienią 1767 r. w Warszawie nuncjusz nadal dodawał odwagi posłom gotowym stanowczo protestować przeciw moskiewskim gwałtom, choć przyznawał, że niewiele mogą osiągnąć tak nieliczne osoby gotowe do poświęceń, do tego narażone na przemoc ${ }^{109}$. O ile wcześniej stanowczo wymagał od biskupów bohaterskiej postawy, ironizując na temat ich słabości i strachu przed rosyjskim ambasadorem (np. sugerował, że przyjęliby Koran, gdyby Repnin tego zażądał ${ }^{110}$, zadał nawet takie pytanie biskupowi kujawskiemu Antoniemu Ostrowskiemu ${ }^{111}$ ) - po

talenti, coraggio e zelo si conservassero per impiegarsi in un tempo tanto interessante. Conveniva procurarsi l'amicizia, confidenza, e credito del Sovrano, del Primate, degli altri Commissari, e per fine dell'Inimico, conveniva che vi fosse stato chi rilevasse con buona maniera, pazienza, e costanza la deformità di alcune concessioni, e chi senza compromettere il proprio carattere avesse potuto insinuare un progetto di disimpegno in risposta all'esorbitante piano formato dai dissidenti, che non dubito, che le sarà stato trasmesso da Mons. Nunzio. Se ogni cosa fosse riuscita inutile allora i zelanti dovevano nella Dieta opporsi vigorosamente, e farsi condurre in Siberia piuttosto che ratificare un'iniquità. In questo caso avrei desiderato anch'io qualche vittima per un monumento perpetuo delle violenze usate, e della invalidità dei stabilimenti, che si fossero fatti", P.L. Silva do L.M. Torrigianiego, Wiedeń, 30 XI 1767, ASV, Segr. Stato Polonia 280, k. 342 343v. Por. ANP 52/1, N. 205.

109 „Io non lascio di coltivare e nutrire il zelo di quei pochi Commissari che mostrano buona intenzione, ma che può sperarsi da questi e pochi, ed esposti alle violenze?", A.M. Durini do L.M. Torrigianiego, Warszawa, 6 I 1768, ASV, Segr. Stato Polonia 281, k. 4v. (por. AD, t. 1, s. 121-124; ANP 52/1, N. 246 z usterkami w transkrypcji; fragmentu brak u Theinera, s. 267).

110 „Sono tutti così atterriti, e disanimati, che se il Repnin proponesse loro l'Alcorano, io sono d'avviso, che l'accetterebbero", A.M. Durini do L.M. Torrigianiego, Warszawa, 11 XI 1767, ASV, Segr. Stato Polonia 280, k. 305-305v. (por. AD, t. 1, s. 68-72; ANP 52/1, N. 178; fragmentu brak u Theinera, s. 240).

111 „Ripigliai io, se dunque il Principe Repnin vi avesse proposto l'Alcorano, l'avreste accettato? Mi rispose di sangue freddo, che alla forza non vi era riparo", 
przedstawieniu w styczniu 1768 r. oficjalnego protestu Stolicy Apostolskiej prosił sekretarza stanu o wzgląd na warunki, w jakich działa: „proszę Waszą Eminencję o rozważenie niebezpieczeństwa, w jakim znajduje się nuncjusz obarczony podobnymi zadaniami, ponieważ mamy tu do czynienia z kimś, kto nie uznaje ani prawa narodów, ani naturalnego"112.

Sprawę projektu obalenia nuncjatury i ustanowienia synodu narodowego należałoby omówić w osobnym studium - nuncjusz odnosił się do tego ryzyka w niemal wszystkich depeszach od końca 1767 do 27 lutego 1768 r., kiedy to mógł z ulgą poinformować Stolicę Apostolską, iż dzień wcześniej z woli Katarzyny II projekt trafił do kosza ${ }^{113}$. Ten pierwszy od miesięcy sukces Durini przypisał aktowi protestu, jaki w imieniu Stolicy Apostolskiej ogłosił z końcem sejmu 1767-1768 r. Konfederacja barska wkrótce jeszcze bardziej rozbudziła nadzieję arcybiskupa na ostateczne zwycięstwo słusznej sprawy. Stolica Apostolska w obliczu nowych wydarzeń ponownie zaleciła nuncjuszowi neutralność polityczną, lecz o przełomie w jego zapatrywaniu na polską rzeczywistość nie mogło być mowy. Nie ulega wątpliwości, że abp Durini widział w nowej konfederacji szansę na odwrócenie losu Rzeczypospolitej i pełną realizację oczekiwań, z którymi rozpoczynał swą misję w Warszawie. Podobnych nadziei nie łączył ze Stanisławem Augustem. Wpłynęło to na jego relacje o wydarzeniach związanych z konfederacją.

Pierwszy rok konfederacji barskiej w depeszach nuncjusza Duriniego

Pierwsze wieści o nowej konfederacji Durini przesłał Torrigianiemu 16 marca 1768 r. ${ }^{114}$ Relacjonował reakcje dworu - mówiono o konfederacji pogardliwie, ale, w głębi serca, stronnicy króla odczuwali strach, dlatego szybko zaczęli się domagać od Repnina wsparcia militarnego.

A.M. Durini do L.M. Torrigianiego, Warszawa, 21 XI 1767, ASV, Segr. Stato Polonia 280, k. 317 (por. AD, t. 1, s. 80-84; ANP 52/1, N. 191; Theiner, s. 242).

112 „supplico V.E. a riflettere il pericolo, in che si trova il Nunzio incaricato di simili commissioni, avendo noi a fare con chi non conosce né il gius delle Genti né di natura", A.M. Durini do L.M. Torrigianiego, Warszawa, 3 II 1768, ASV, Segr. Stato Polonia 281, k. 19 (por. AD, t. 1, s. 150-152; ANP 52/1, N. 268). Brak u Theinera. O niebezpieczeństwie deportacji nuncjusza zob. D. Caccamo, op. cit., s. 44-45; por. J.T. Łukowski, op. cit., s. 85.

113 A.M. Durini do L.M. Torrigianiego, Warszawa, 27 II 1768, ASV, Segr. Stato Polonia 281, k. 24 (por. AD, t. 1, s. 155-157); ANP 52/1, N. 289. Brak u Theinera.

114 ASV, Segr. Stato Polonia 281, k. 42 (por. AD, t. 1, s. 180-182; ANP 52/1, N. 305). Brak u Theinera. 
Niektórzy dowódcy wojsk królewskich odmówili interwencji, powołując się na fakt, iż nie wysłano wojsk przeciw konfederacjom dysydenckim w Słucku i Toruniu, więc jakże mieliby maszerować przeciw katolikom zgromadzonym pod hasłami „wiary i wolności, mającej krzyż za godło” 115 .

W początkach ruchu barskiego niepewność stronnictwa dworskiego oraz ambasadora Repnina dotyczyła, zdaniem Duriniego, ewentualnej pomocy zagranicznej dla konfederatów. List bpa Ignacego Massalskiego z Paryża aluzyjnie zapowiadał iż „wkrótce Bóg nas pocieszy”, Repnin natomiast deklarował publicznie, że Turcja nie będzie się angażowała w nowy konflikt ${ }^{116}$. Król w opinii Duriniego gorliwie zabiegał o uzyskanie dodatkowej pomocy militarnej Rosji i „niemal padał do nóg” członkom Rady Senatu, by podpisali stosowną petycję ${ }^{117}$.

Wbrew oczekiwaniom dworu i ambasadora, pogłosek budzących nadzieję na sukces nowej konfederacji nie brakowało. Wieści z Porty w początkach kwietnia donosiły o tureckim sprzeciwie wobec zwiększania liczby rosyjskich wojsk w Rzeczypospolitej, twierdzono za rezydentem mołdawskim Pierre'em de la Roche, że Turcy wkrótce wkroczą do Polski, czego zapowiedzią było ultimatum wystosowane w Konstantynopolu: Rosja powinna uwolnić przetrzymywanych polskich senatorów, w przeciwnym wypadku do aresztu trafi rosyjski ambasador w Turcji. Oprócz dobrych wiadomości znad Bosforu, z nowin krajowych, którym ufał Durini, wynikało, iż potyczki konfederatów z wojskami rosyjskimi przyniosły zwycięstwa pierwszym ${ }^{118}$, a wieści z Moskwy kazały wierzyć, że Katarzyna II nie odważy się prowokować konfliktu z Portą i nie wprowadzi do Polski dalszych wojsk ${ }^{119}$.

Nuncjusz w tym czasie kilkakrotnie zadeklarował sekretarzowi stanu swą pełną neutralność, zgodnie z poleceniami Stolicy Apostolskiej:

115 ASV, Segr. Stato Polonia 281, k. 43.

116 A.M. Durini do L.M. Torrigianiego, 23 III 1768, ASV, Segr. Stato Polonia 281, k. 46v. (por. AD, t. 1, s. 182-183; ANP 52/1, N. 310). Brak u Theinera.

117 A.M. Durini do L.M. Torrigianiego, 30 III 1768, ASV, Segr. Stato Polonia 281, k. 50 (por. AD, t. 1, s. 184-186). Brak u Theinera. Ówczesną postawę króla w negatywnych barwach ukazał także W. Konopczyński, op. cit., t. 1, s. 58-60.

118 „Nelle vicinanze di Bar in un luogo detto Viniza corre voce che siansi azzuffati i Confederati co' Moscoviti là acquartierati colla peggio di questi”, A.M. Durini do L.M. Torrigianiego, 6 IV 1768, ASV, Segr. Stato Polonia 281, k. 87 (por. AD, t. 1, s. 186-187; ANP 52/1, N. 321). Brak u Theinera. W ciągu kolejnego roku pojawią się w depeszach nuncjusza dziesiątki podobnych informacji.

119 „Si vociferò subito dell'ordine venuto ai Generali Moscoviti di attaccare i Confederati se credono di potersi battere, ma che la Corte di Pietroburgo non intendeva di mandare altre truppe. Dal che si conlude che la Czarina teme di una irruzione di Turchi ne' suoi stati", A.M. Durini do L.M. Torrigianiego, 27 IV 1768, ASV, Segr. Stato Polonia 281, k. 93 (por. AD, t. 1, s. 190-191). Brak u Theinera. 
Wykonałem już i nadal będę wykonywał polecenie Waszej Eminencji zawarte w depeszy z 16 kwietnia, dotyczące mojego sposobu postępowania w obecnych krytycznych warunkach, które odznacza się rozważną obojętnością, by nie dać dworowi powodu do podejrzeń. Czas pokaże, czy z tego fermentu może zrodzić się jakaś nadzieja dobra dla katolickiej wiary. Jakkolwiek by było, [konfederacja] rozrasta się każdego dnia i jak dotąd przewaga jest po stronie konfederatów ${ }^{120}$.

Deklarację neutralności Durini ponawiał w ciągu czerwca 1768 r. kilkakrotnie $^{121}$.

Osobiste przekonania i nadzieje nuncjusza kształtowały się jednak zgoła odmiennie, a z treści depesz w omawianym okresie wynika jego pełne poparcie dla zawiązywanych w Rzeczypospolitej konfederacji. Arcybiskup Durini niemal co tydzień, choćby tylko zdawkowo, informował kard. Torrigianiego o kolejnych sukcesach konfederatów - w jednej z relacji uznał ich za zdolnych do skutecznej walki samymi tylko szablami przeciw armatom. Informacje o kontrakcji wojsk rosyjskich lub królewskich nuncjusz także przekazywał sekretarzowi stanu, lecz zwykle zgłaszał spore wątpliwości co do ich wiarygodności (tego rodzaju zastrzeżenia nigdy nie towarzyszyły relacjom o dokonaniach konfederackich). $\mathrm{Z}$ tekstów tych można by ułożyć prawdziwą antologię, niech więc wystarczy po jednym przykładzie entuzjastycznych doniesień nuncjusza o sukcesach konfederatów oraz dezawuowania opinii krytycznych o szansach powodzenia konfederacji w konfrontacji z regularną armią rosyjską. W czerwcu 1769 r. Durini w liście do sekretarza stanu wyrażał się z uznaniem o dzielności żołnierzy konfederacji, nazywanej przez dwór rosyjski fanatyzmem - mieli m.in. z powodzeniem zdobywać pozycje artyleryjskie dzięki brawurowym szarżom kawalerii ${ }^{122}$.

Władysław Konopczyński wspomniał w swej monografii konfederacji barskiej, jak bardzo cały naród życzył konfederatom powodzenia

120 „Già ho eseguito, ed eseguirò quanto si è degnato V.E. suggerirmi coi suoi Numeri dei 16 scorso circa la condotta, che io devo tenere nelle presenti critiche circostanze, regolandomi con prudente indifferenza per non dar motivo alla corte d'insospettirsi di me. Il tempo ci chiarirà, se vi sia da sperare alcun bene in pro della Religione Cattolica da questa fermentazione. A buon conto va crescendo ogni giorno, e il vantaggio fin ora è dalla parte dei confederati”, A.M. Durini do L.M. Torrigianiego, 11 V 1768, ASV, Segr. Stato Polonia 281, k. 101 (por. AD, t. 1, s. 193-195; ANP 52/2, N. 356 [transkrypcja pomija „ed eseguirò"]). Brak u Theinera.

121 A.M. Durini do L.M. Torrigianiego, 1, 8 i 22 VI 1768, ASV, Segr. Stato Polonia 281, k. 117, 122, 130 (por. AD, t. 1, s. 199-202, 216-217; ANP 52/2, N. 377, 381, 393). Theiner, s. 270, przytacza tylko pierwsze z pism, w ANP list z 8 VI bez początku.

122 A.M. Durini do L.M. Torrigianiego, 15 VI 1768, ASV, Segr. Stato Polonia 281, k. 125-v. (por. ANP 52/2, N. 386; Theiner, s. 270). 
i jak łatwo dawano wiarę najbardziej nieprawdopodobnym opowieściom o klęskach rosyjskich ${ }^{123}$. Nie ulega wątpliwości, że i nuncjusz Durini życzył Polsce ostatecznego wyzwolenia spod kurateli moskiewskiej, tym chętniej donosił o narastającym kryzysie stronnictwa królewskiego oraz o niełasce, w jaką popadał Repnin. Dawał też wiarę dobrym, lecz nie do końca sprawdzonym wiadomościom o sukcesach konfederatów, a relacje przeciwne traktował jako wrogą propagandę Rosji i królewskiego dworu, zmierzającą do osłabienia w narodzie ducha oporu:

W poniedziałek 27 rano do księcia Repnina dotarł kurier z Podola i następnie rozpowszechniono wiadomość, że forteca Berdyczów skapitulowała przed generałem Kreczetnikowem [Petr Krečetnikov], a generał Apraksin zdobył Bar, wycinając w pień 800 konfederatów i biorąc do niewoli 1500, wśród nich wielu przywódców; ale powszechnie się powątpiewa o tym zwycięstwie, albo przynajmniej uważa się za przesadzone, by zastraszyć Polaków [--]. Tej samej nocy poniedziałkowej 27 dotarł do księcia Repnina drugi kurier z wiadomością, że konfederaci odbili Bar i Berdyczów z wielkimi stratami Moskali ${ }^{124}$.

W drugiej połowie 1768 i na początku 1769 r. styl wypowiedzi nuncjusza pozostał niezmieniony, tj. w depeszach dotyczących konfederacji barskiej - a raczej wielu konfederacji, które gromadziły się ad mentem Barensis - podkreślał ich liczebny rozwój, militarne sukcesy, rosnący strach dworu i Rosjan. Oddanie pola wojskom rosyjskim czy królewskim było dla dyplomaty raczej taktycznym ustępstwem, nierzadko przeradzającym się w zwycięstwo konfederatów. Przegrana - jak np. utrata Krakowa - stanowiła skutek zdrady, inspirowanej przez dwór królewski:

${ }^{123}$ W. Konopczyński, op. cit., t. 1, s. 68-69. Domenico Caccamo pisze, że już latem 1768 r. zaczęto w Rzymie wątpić w faktyczne podstawy optymizmu Duriniego; wybuch wojny rosyjsko-tureckiej przysporzył mu nieco więcej zaufania, którym obdarzał go kard. Lazzaro Opizio Pallavicini, nowy sekretarz stanu, przez cały rok 1769, by później znów nabrać krytycznego dystansu. D. Caccamo, op. cit., s. 48-49.

124 „Lunedì 27 mattina giunse corriere al Principe Repnin dalla Podolia, ed in seguito si sparse la nuova, che la fortezza di Berdyczow si era resa per capitolazione al Generale Chrzeczernikow, e che i Generale Apraxin si fosse impadronito di Bar, avendo tagliato a pezzi 800 di quei Confederati, e fattine prigionieri 1500, fra i quali molti dei principali, ma di tale vittoria, quale si ragiona, se ne dubita fortemente, e si crede esagerata per intimorire gli altri Palatinati [--]. La notte poi dell'istesso Lunedì 27 giunse un secondo corriere al Principe Repnin colla nuova, che i confederati avevano ripreso e Bar, e Berdyczew con gran rotta dei Moscoviti”, A.M. Durini do L.M. Torrigianiego, 29 VI 1768, ASV, Segr. Stato Polonia 281, k. 136v.-137, 137v.-138 (por. ANP 52/2/402; Theiner, s. 271). W transkrypcji ANP brak ,ed in seguito si sparse la nuova”. Theiner opuszcza cały ten fragment w swej transkrypcji, przepisując jedynie początek i koniec listu. 
Zdobycie Krakowa przez Moskali uważa się za pewne - zaatakowali miasto wszystkimi siłami w nocy 16 i po siedmiu godzinach walki pokonali je. To zwycięstwo zawdzięcza jednak więcej pieniądzom, niż sile zbrojnej. Wielu poświadcza, że w szeregach konfederatów doszło do zdrady i mówi się głównie o [Aleksandrze] Łętowskim, podczaszym krakowskim, który był zawsze człowiekiem przywiązanym do dworu i niecnie przyłączył się do konfederacji, by ją później zdradzićn ${ }^{125}$.

Intrygi dworskie i moskiewskie miały też leżeć u genezy buntów chłopskich na Ukrainie, a krew ofiar - jak ujął to nuncjusz - będzie wołała do nieba o pomstę nad oprawcami, ale jeszcze bardziej nad tymi, którzy ich do złego nakłonilii ${ }^{126}$. Z kolei w siłę rosła konfederacja na Litwie i w Wielkopolsce, a inne oddziały konfederackie przygotowywały się do zdobycia twierdzy w Kamieńcu Podolskim ${ }^{127}$. Nuncjusz nie wypowiadał się krytycznie o problemach trapiących konfederatów, raz, i to zdawkowo, zasugerował jedynie, że jeszcze większe sukcesy odnieśliby, mając jednego przywódcę (,una testa che governasse”) ${ }^{128} .18$ stycznia $1769 \mathrm{r}$. Durini pisał: „Konfederacje codziennie rosną w siłę i można już powiedzieć, że cała Polska jest skonfederowana; niedawno kilka kilometrów od Warszawy wycięto w pień 300 Rosjan"129.

Na początku września 1768 r. król zwrócił się do abpa Duriniego z sugestią, by zabrał głos w sprawie duchownych, którzy wykorzystują konfesjonał dla rozpowszechniania idei konfederackich. Nuncjusz był taką sugestią zaskoczony i podkreślił, że czuwanie nad spowiednikami

125 „Si tiene per fermo, che Cracovia sia venuta in potere dei Moscoviti, che l'attaccarono con ogni sforzo la notte dei 16, e dopo sette ore di combattimento la presero. Questa vittoria però più che all'armi si attribuisce al denaro, convenendo molti, che per parte di tre principali confederati vi sia stato tradimento, e si parla particolarmente di Łętowski coppiere di Cracovia, che fu sempre uomo addetto alla Corte, e maliziosamente entrò in confederazione per poi tradirla", A.M. Durini do L.M. Torrigianiego, Warszawa, 24 VIII 1768, ASV, Segr. Stato Polonia 281, k. 168 (por. AD, t. 1, s. 231-232; ANP 52/2, N. 442). Brak u Theinera.

126 A.M. Durini do L.M. Torrigianiego, Warszawa, 14 IX 1768, ASV, Segr. Stato Polonia 281, k. 184v. (por. AD, t. 1, s. 251-252; ANP 52/2, N. 456; Theiner, s. 272).

127 A.M. Durini do L.M. Torrigianiego, Warszawa, 23 XI 1768, ASV, Segr. Stato Polonia 281, k. 233v. (por. AD, t. 1, s. 272-273; ANP 52/2, N. 507; Theiner, s. 276).

128 A.M. Durini do L.M. Torrigianiego, Warszawa, 21 IX 1768, ASV, Segr. Stato Polonia 281, k. 186 (por. AD, t. 1, s. 254-256; ANP 52/2, N. 460; Theiner, s. 273).

129 „Le Confederazioni crescono ogni giorno, ed ormai può dirsi che tutta la Polonia è confederata, ed ultimamente a poche leghe di Varsavia sono stati tagliati a pezzi da 300 Russi”, A.M. Durini do L.M. Torrigianiego, Warszawa, 18 I 1769, ASV, Segr. Stato Polonia 282, k. 134. Kilka dni później, 21 I 1769 r., pisał: „il partito acattolico [sta] sul punto di vedersi annichilito", ibidem, k. 136 (por. AD, t. 1, s. 292-293, 294; ANP 52/2, N. 548, N. 549). Brak u Theinera. 
należy do obowiązków biskupów diecezjalnych. Przeczuwał jednocześnie, że był to jedynie wybieg, by skłonić go do wypowiedzenia się przeciwko konfederacji, według życzeń dworu ${ }^{130}$. Zdaniem Duriniego za tego rodzaju insynuacjami stał jeden z najzagorzalszych krytyków Stolicy Apostolskiej w Polsce, sekretarz królewski kanonik Gaetano Ghigiotti - przyjaciel dysydentów, wróg zakonów, Stolicy Apostolskiej i nuncjatury ${ }^{131}$, który wprost powiedział nuncjuszowi, iż „dobrze widzi, że Rzym i ja jesteśmy bardziej skłonni sprzyjać konfederacji, niż królowi"132. Nuncjusz wciąż podkreślał swą neutralnośćci33, a 1 października $1768 \mathrm{r}$. wystosował do sekretarza stanu długi list w swej obronie, nazywając się m.in. „dobrym i gorliwym dyplomatą" („buono e zelante ministro”):

Wasza Eminencja zbyt kocha i pilnuje sprawiedliwości i bezstronności, by potępić nuncjusza, zanim wysłucha jego argumentów i dlatego pragnę poddać je rzetelnemu osądowi Waszej Eminencji, tłumacząc się z całą otwartością, która przystoi nuncjuszowi i nie będzie uchybieniem szacunku należnego Waszej Eminencji. [--] Odpowiem, że dzięki Bogu, który mną kieruje w tej Babilonii, nie obawiam się niesławy u dobrych tego narodu, którzy hołdują prawdzie i otrzymali wiele dowodów mojej gorliwości i bezkompromisowości w służbie Stolicy Apostolskiej. [--] Gdyby nawet królowi udało się nakłonić republikę do [przyjęcia uchwały o moim usunięciu, na podobieństwo nuncjusza Vincenza Santiniego], zamiast widzieć w tym coś złego, przyjmę to jako znak Bożej Opatrzności, która zechce, bym opuścił ten piekielny chaos $^{134}$.

130 „la Corte certamente avrebbe desiderato spiccarmi dalle mani qualche atto pubblico di disapprovazione, ma non vi voleva molta finezza per capire che la mira sua era da un lato d'infamare il sacerdozio, e dall'altro di far così qualificare l'unione dei confederati per vera ribellione", A.M. Durini do L.M. Torrigianiego, Warszawa, 7 IX 1768, ASV, Segr. Stato Polonia 281, k. 182 (por. AD, t. 1, s. 247-251; ANP 52/2, N. $452-$ z zastrzeżeniem, gdyż sygnatury $\mathrm{w}$ aparacie naukowym transkrypcji błędnie oznaczają w jednym ciągu kopię i oryginał, transkrypcja dokonana jest według kopii, nie oryginału, zaznaczono też edycję u Theinera, podczas gdy jest ona wybiórcza i cytowanego fragmentu nie zawiera).

131 A.M. Durini do L.M. Torrigianiego, Warszawa, 7 IX 1768, ASV, Segr. Stato Polonia 281, k. 182 nn. Por. D. Caccamo, op. cit., s. 46-47.

132 „vedeva bene, che Roma, ed io eramo più portati a favorire la Confederazione che il Re", A.M. Durini do L.M. Torrigianiego, Warszawa, 7 IX 1768, ASV, Segr. Stato Polonia 281, k. 182v.; fragmentu brak u Theinera.

133 A.M. Durini do L.M. Torrigianiego, Warszawa, 16 XI 1768 oraz 3 XII 1768, ASV, Segr. Stato Polonia 281, k. 225v. i 250v. (por. AD, t. 1, s. 271-272 i 284-285; ANP 52/2, N. 501, N. 516; pierwszy z fragmentów Theiner opuścił, drugi przepisał, s. 277).

134 „V.E. è troppo amante ed osservante del giusto, e dell'equità per non condannare un nunzio prima di avere sentite le sue ragioni, e però mi assicuro di esporle al suo sodo giudizio, spiegandomi con quella libertà, che compete al carattere di Nunzio, 
List był odpowiedzią na depeszę sekretarza stanu z 20 września 1768 r., w której podsumowano szereg zarzutów i zażaleń przeciwko nuncjuszowi. Arcybiskup Durini był przekonany, że ich rozpowszechnianie stanowiło skutek intryg niechętnego mu Tommasa Anticiego. Uznał wręcz, że list został zredagowany bez pełnej wiedzy sekretarza stanu, a niektóre stawiane mu zarzuty wyszły spod pióra sekretarza redagującego czystopis depeszy, który przyjaźnił się z Anticim i nadużył swej pozycji, by własną, przesadnie negatywną ocenę dyplomaty ukazać jako opinię samego kard. Torrigianiego ${ }^{135}$.

Korzystny, jak go postrzegał abp Durini, rozwój konfederacji barskiej miał potwierdzać słuszność jego sposobu postępowania. Pod koniec $1768 \mathrm{r}$. król, prymas i dysydenci zdawali się powoli wycofywać z wcześniej prowadzonej polityki, ale zdaniem nuncjusza tego rodzaju taktyczny manewr nic im miał nie dać. 9 listopada Durini pisał: „Liczni dysydenci w Warszawie spontanicznie wyrzekają się tego wszystkiego, co uchwalono na ich korzyść na ostatnim sejmie, ale jest już za późno"136. Ten sam komentarz („troppo tardi” - za późno) dotyczył gorączkowych narad króla i jego doradców w początkach grudnia. Zbliżała się godzina sprawiedliwości ${ }^{137}$, a wybić miała już podczas najbliższej wiosny („la Primavera scioglierà tutto questo aggruppamento degli affari di Polonia"138). 4 stycznia $1769 \mathrm{r}$.

e che non può mai intaccare in menoma parte la venerazione dovuta a V.E. [- - ] Rispondo che grazie a Dio, che mi regge in questa Babilonia, non temo di veruna macchia presso i Buoni di questa nazione, che rendono omaggio al vero, e che hanno più riprove del mio disinteresse e zelo nel servizio della S. Sede. [--] quand'anche riuscisse al Re di spuntarlo [un decreto della Repubblica, con cui si domandi il mio rappello] dalla Repubblica, anziché averlo per male, lo avrei per un tratto della Divina Providenza, che mi vorrebbe uscire da questo bulicame d'Inferno", A.M. Durini do L.M. Torrigianiego, $1 \mathrm{X} 1768$, AD, t. 1, s. 257-261. Brak u Theinera. Oryginalnej depeszy brak też w tomach ASV, Segr. Stato Polonia 276, 281 i 282. W ANP 52/2, N. 468 dokonano jej transkrypcji na podstawie ASV, Segr. Stato Polonia, Additamenta 12, s.f.

135 A.M. Durini do L.M. Torrigianiego, 1 X 1768, AD, t. 1, s. 257.

136 „Molti dissidenti esistenti in Varsavia esibiscono spontaneamente di rinunziare a tutto ciò che è stato stabilito a favor loro nell'ultima Dieta, ma troppo tardi", A.M. Durini do L.M. Torrigianiego, Warszawa, 9 XI 1768, ASV, Segr. Stato Polonia 281, k. 224r.-v. (por. AD, t. 1, s. 269-271; ANP 52/2, N. 496; fragment opuszczony przez Theinera, s. 275).

137 „Gran Consigli si tengono per svolgersi dalla stoppa, in cui sono inviluppati, ma troppo tardi, e mentre si consulta qui i Confederati guadagnano terreno, e bene sta che sia ridotto all'estremità, chi ha voluto spingere le cose all'estremo. Est Deus in Israel. In queste circostanze io mi tengo lontano da tutti i Polacchi ed in una scrupolosissima neutralità", A.M. Durini do L.M. Torrigianiego, Warszawa, 3 XII 1768, ASV, Segr. Stato Polonia 281, k. 250-250v. (por. AD, t. 1, s. 284-285; ANP 52/2, N. 516; Theiner, s. 278).

138 A.M. Durini do L.M. Torrigianiego, Warszawa, 28 XII 1768, ASV, Segr. Stato Polonia 282, k. 125 (por. AD, t. 1, s. 289-290; ANP 52/2, N. 535; Theiner, s. 277). 
nuncjusz deklarował: „partia rosyjska i dworska są w trudnej sytuacji, rozpadają się i pakują manatki"139. W kolejnym tygodniu, po informacji o sukcesach wojsk konfederackich w Wielkopolsce, nuncjusz podkreślał rosnące osamotnienie króla. Stanisław August myślał rzekomo o zwołaniu konfederacji wokół króla i dworu, ale musiał zrezygnować z takiego projektu, który nie miał szansy powodzenia ${ }^{140}$.

22 lutego nuncjusz odebrał od kuriera wiadomość o śmierci Klemensa XIII, która nastąpiła 2 lutego w Rzymie ${ }^{141}$. Mógł zapewne żałować, że papież, który wysłał go do Rzeczypospolitej, nie doczekał ostatecznego triumfu sprawy konfederackiej, oczekiwanego przez nuncjusza w ciągu najbliższych tygodni.

W rzeczy samej, zdaniem Duriniego los Rzeczypospolitej miał się odmienić definitywnie wiosną 1769 r. Nuncjusz oczekiwał szybkiego odwołania Repnina do Rosji i żył wrażeniem nieustannych postępów konfederacji oraz rosnącej w siłę antyrosyjskiej koalicji międzynarodowej. Repnin co prawda nadal postępował arogancko - np. wszedłszy do teatru w połowie sztuki nakazał odegranie jej od początku, lecz nuncjusz skomentował to następująco:

Można o nim powiedzieć to, co Tasso napisał o Argancie:

- Umarł, a jeszcze grozi.

Bliski jest już czas, kiedy Polska zobaczy

- atque alios soles atque alia sidera.

Przewidziałem tę metamorfozę od mojego przybycia do Warszawy i postępowałem stosownie do tych oczekiwań. Biedna byłaby nuncjatura i ja byłbym pożałowania godny, gdybym podążył śladem mojego Poprzednika [Viscontiego] i pił wodę z tej samej fontanny! Ale dzięki Bogu nie pomyliłem świetlików z latarniami. Pośród tej tragedii, która właśnie dobiega końca, jestem spokojny o moją postawę i patrzę wszystkim prosto w oczy. Jeszcze dwa miesiące i potęga moskiewska w Polsce zostanie unicestwiona ${ }^{142}$.

139 „Il Partito Russo e quello della Corte è molto intrigato, e anche sparito, e fanno fagotto", A.M. Durini do L.M. Torrigianiego, Warszawa, 4 I 1769, ASV, Segr. Stato Polonia 282, k. 126v. (por. AD, t. 1, s. 290-291; ANP 52/2, N. 539). Brak u Theinera.

140 A.M. Durini do L.M. Torrigianiego, Warszawa, 4 I 1769, ASV, Segr. Stato Polonia 282, k. 129 (por. AD, t. 1, s. 290-291; ANP 52/2, N. 544). Brak u Theinera. O tych zamysłach króla, zob. D. Dukwicz, Król Stanisław August w latach 1769-1770 w świetle korespondencji z Franciszkiem Ksawerym Branickim, w: W cieniu wojen i rozbiorów. Studia z dziejów Rzeczypospolitej XVIII i początków XIX wieku, red. U. Kosińska, D. Dukwicz, A. Danilczyk, Warszawa 2014, s. 281.

141 A.M. Durini do L.M. Torrigianiego, Warszawa, 22 II 1769, ASV, Segr. Stato Polonia 282, k. 155 (por. AD, t. 1, s. 301-302). Brak u Theinera.

142 „Ben si può dire di lui quello che il Tasso diceva di Argante:

- E morto ancor minaccia. 
Przytoczony wyżej szeroko obraz poglądów Duriniego na konfederację barską pozwala nie tylko poznać reakcję dyplomaty na wydarzenia, których był świadkiem, oraz jego zdolność do krytycznej oceny otrzymywanych informacji. Skłania on także do konkluzji o skłonności nuncjusza do niezwykle jednostronnego i nader życzeniowego widzenia rzeczywistości. Ta perspektywa nie jest bez znaczenia dla rozważań o charakterze dyplomatycznej działalności rzymskiego dyplomaty w okresie konfederacji radomskiej i sejmu repninowskiego.

\section{Zakończenie}

Celem niniejszego artykułu było ponowne spojrzenie na spór historiograficzny dotyczący postawy nuncjusza Duriniego w okresie poprzedzającym konfederację barską oraz w burzliwych miesiącach jej pierwszych zwycięstw i porażek. Ponowne sięgnięcie do źródeł archiwalnych wykazało wybiórczość edycji Theinera, który pominął wiele istotnych depesz, a niektóre wydrukował jedynie we fragmentach. Nowsza edycja w ramach serii Acta Nuntiaturae Polonae jest pod tym względem znacznie lepsza, choć także niewolna od drobnych usterek. W większości nie przeszkadzają one w zrozumieniu treści depesz, choć pełniejsza ich analiza domagałaby się artykułu recenzyjnego. Niniejszy artykuł nie stawiał sobie takiego zadania, koncentrując się na próbie nowej lektury źródeł z zamiarem ponownego przemyślenia postawy nuncjusza apostolskiego w kluczowym dla Rzeczypospolitej okresie.

Jak można było zauważyć, abp Durini często powoływał się na swą skrupulatność w wypełnianiu dyrektyw Stolicy Apostolskiej, zawartych w otrzymanej Instrukcji i późniejszych depeszach, oraz deklarował całkowitą neutralność polityczną. Jednocześnie nie chciał albo nie potrafił zaakceptować realiów Rzeczypospolitej i jedyne słuszne działanie upatrywał w ostrej konfrontacji z dworem królewskim i rosyjskim ambasadorem. Było to dalekie przynajmniej od części zaleceń wspomnianej

Si accosta a furia il tempo, in cui la Polonia vedrà

- atque alios soles atque alia sidera.

Questa metamorfosi fu da me preveduta fin dal mio ingresso in Varsavia, e mi sono misurato in conseguenza. Povera Nunziatura, e meschino me, se avessi seguitato le pedate del mio buon Antecessore, ed avessi bevuto all'istessa fontana! Ma grazie a Dio non ho preso lucciole per lanterne. In mezzo a questa tragedia che già tocca allo scioglimento, io me ne sto quieto pe' fatti miei, ed in finestra. Anche due mesi, e la potenza Moscovitica in Polonia sarà annichilita", A.M. Durini do L.M. Torrigianiego, 14 I 1769, ASV, Segr. Stato Polonia 282, k. 129v.-130 (por. AD, t. 1, s. 291-292; ANP 52/2, N. 544). Brak u Theinera. 
Instrukcji oraz od postawy jego poprzednika, nuncjusza Viscontiego, który wydawał się reprezentować tradycję wytrawnej dyplomacji rzymskiej, nienawykłej do ostrej konfrontacji tam, gdzie mogła ona tylko pogorszyć sprawę. Jak już zauważono, w historiografii przyjmowano raz jeden, raz drugi sposób interpretacji postawy nuncjusza. Ponowna analiza najbardziej oficjalnych źródeł pozwoliła jednak na dostrzeżenie kolejnego aspektu osobowości abpa Duriniego, dotąd - jak się wydaje - niezaakcentowanego wystarczająco. Krytyczne spojrzenie nuncjusza ogarniało nie tylko tę część polskiego społeczeństwa, która sprzyjała polityce Stanisława Augusta i jego dworu, ale także dotyczyło jego poprzednika na stanowisku reprezentanta Stolicy Apostolskiej w Warszawie - abpa Viscontiego. Ten hierarcha, nie rezygnując ze stanowczości w prezentowaniu postulatów Stolicy Apostolskiej w tak samo burzliwym dla Polski czasie i w podobnym kontekście, inaczej rozumiał „skrupulatne wypełnianie dyrektyw papieża". Stolica Apostolska nakazywała wypowiedzenie non possumus w sytuacji całkowitej realizacji rosyjskiej polityki wyznaniowej na terytorium Rzeczypospolitej. Jednocześnie sugerowała daleko posunięte możliwości kompromisu, ze świadomością druzgocącej przewagi militarnej Rosji i obawą zastosowania przez Moskwę argumentu siły w pełnym wymiarze już bezpośrednio przeciw Stolicy Apostolskiej. Wydaje się, że nuncjusz Durini tej części instrukcji nie zamierzał realizować. Nie widać w jego depeszach śladu działań, które świadczyłyby o próbie oddalenia w czasie momentu, gdy wypowiedzenie non possumus stanie się jedynym możliwym wyjściem. Konsekwencje polityki opartej o ostrą konfrontację ze stronnictwem dworskim i Repninem są znane. Styl działania i rozumowania nuncjusza Duriniego - tak różny nie tylko od jego następców, ale i od bezpośredniego poprzednika w Warszawie - nie pozwolił nam poznać, jakie byłyby konsekwencje inspirowania innego sposobu działania opozycji antykrólewskiej.

Pozostaje pytanie o źródło tak stanowczych przekonań i nieraz jednostronnych ocen osób i sytuacji, zawartych w depeszach Duriniego. Biorąc pod uwagę odmienną postawę abpa Viscontiego, nie można uznać postawy Duriniego za jedyny realny sposób wiernego służenia Stolicy Apostolskiej w ówczesnym kontekście politycznym. Może jego poglądy i wynikłe z nich działania były związane z polityką zagraniczną Francji, której Durini był bliski ideowo ${ }^{143}$ ? A może miały źródło w podziałach istniejących w łonie kurii rzymskiej, na co wskazywałyby stosunkowo częsta krytyka opinii i postępowania Viscontiego?

${ }^{143}$ Pytanie to stawiał już Domenico Caccamo, op. cit., s. 50 nn., optując za mocnym wpływem polityki profrancuskiej na przekonania Duriniego. 


\section{Streszczenie}

Postawa Angela Marii Duriniego w okresie sejmu radomskiego i konfederacji barskiej od dawna interesowała historyków czasów stanisławowskich. Skomplikowana sytuacja geopolityczna Rzeczypospolitej oraz wewnętrzne napięcia między królem oraz opozycją antykrólewską, zaognione instrumentalnym wykorzystaniem sprawy dysydenckiej, domagały się szczególnej zręczności dyplomatycznej. Pytanie o tę właśnie cechę w przypadku papieskiego reprezentanta w Warszawie w latach 17671772 przyświecało ponownej lekturze podstawowych źródeł związanych z dyplomatyczną misją Duriniego. Zwrócono uwagę na dwuznaczności zawarte w rzymskiej Instrukcji dla papieskiego dyplomaty, sugerujące możliwość dostosowania konkretnych działań do realnych możliwości: była w niej mowa o niezmiennym obowiązku stanowczej obrony katolicyzmu, a jednocześnie pojawiały się wskazania, by troszczyć się o trwały spokój w Rzeczypospolitej oraz zapobiegać niebezpieczeństwom, które mogłyby grozić „dworowi i narodowi”. Choć Durini wielokrotnie deklarował swoją neutralność w relacji do dworu i opozycji, nie znaleziono w depeszach śladu rzeczywistej subtelności dyplomatycznej, która wydawała się być częścią wcześniejszego doświadczenia warszawskiej nuncjatury z początku panowania Stanisława Augusta. Co więcej, Durini był nie tylko otwarcie krytyczny wobec dworu królewskiego, ale także wobec swego poprzednika w Warszawie, nuncjusza Antonia Eugenia Viscontiego. Lektura pełnego tekstu depesz nuncjatury (w edycji Theinera podanych jedynie w wyborze i okrojonej wersji) ukazuje Duriniego jako dyplomatę, któremu obca była koncepcja kompromisu, a jednocześnie każe przypuszczać, że jego sposób obrony praw Kościoła katolickiego i niepodległości Rzeczypospolitej nie był jedyną możliwą formą realizacji wskazań papieskiej Instrukcji.

\section{The Warsaw Mission of Nuncio Angelo Durini, from Its Inauguration until the End of the First Year of Bar Confederation (July 1767 - February 1769)}

Angelo Maria Durini's stance during the Radom Sejm and the Confederation of Bar has long been of interest to historians of the times of King Stanisław August. The complicated geopolitical situation of the Commonwealth and internal tensions between the king and the anti-royal opposition, inflamed by the instrumental use of the dissident cause, demanded special diplomatic skill. It was the question about this feature of the papal representative in Warsaw in 1767-1772 that guided the re-reading of the basic sources related to Durini's diplomatic mission. Attention has been drawn to the ambiguities of the Instruction for the papal diplomat, allowing for the possibility of various actions depending on the circumstances: it spoke about the permanent obligation firmly to defend Catholicism in Poland, while at the same time it suggested efforts should be taken to preserve peace in the Commonwealth and prevent dangers that could threaten the "court and the nation." Although Durini repeatedly declared his neutrality in relations with the court and the opposition, there is no trace of actual diplomatic subtlety in his 
dispatches, which seemed to be part of the earlier policy of the Warsaw nunciature at the early days of King Stanisław August. Moreover, Durini was not only openly critical of the royal court, but also of his predecessor in Warsaw, Nuncio Eugenio Visconti. Reading the full text of the nuncio's messages (Augustin Theiner's edition gives only a selection of the dispatches in an abridged version) shows Durini as a diplomat unfamiliar with the concept of compromise, and at the same time suggests that his way of defending the rights of the Catholic Church and the independence of the Polish-Lithuanian Commonwealth was not the only possible form of implementing the pope's instructions.

Translated by Grażyna Waluga

\section{Bibliografia}

Acta Nuntiaturae Polonae, t. 52: Angelus Maria Durini (1767-1772), cz. 1: 12 IV 1766 - 20 IV 1768, wyd. Wojciech Kęder, PAU, Cracoviae 2016.

Acta Nuntiaturae Polonae, t. 52: Angelus Maria Durini (1767-1772), cz. 2: 23 IV 1768 - 15 II 1769, wyd. Wojciech Kęder, PAU, Cracoviae 2017.

Caccamo Domenico, Il nunzio A.M. Durini (1767-72) e la prima spartizione di Polonia, w: Italia Venezia e Polonia tra illuminismo e romanticismo, wyd. Vittore Branca, Leo S. Olschki Editore, Firenze 1973, s. 37-68.

Correspondance de Stanislas-Auguste avec Catherine II et ses plus proches collaborateurs (1764-1796), wyd. Zofia Zielińska, Arcana, Kraków 2015.

Correspondance inédite du roi Stanislas-Auguste Poniatowski et de Madame Geoffrin (17641777), wyd. Charles De Mouÿ, Plon, Paris 1875.

De Benedetti F. Augusto, La diplomazia pontificia et la prima spartizione della Polonia, Tip. Flori e Biagini, Pistoia 1896.

Duda Etienne, Le Saint-Siège devant les événements politiques de Pologne à la veille de son premier partage, „Sacrum Poloniae Millenium” 1, 1954, s. 139-207.

Dukwicz Dorota, Król Stanisław August w latach 1769-1770 w świetle korespondencji $z$ Franciszkiem Ksawerym Branickim, w: W cieniu wojen i rozbiorów. Studia z dziejów Rzeczypospolitej XVIII i początków XIX wieku, red. Urszula Kosińska, Dorota Dukwicz, Adam Danilczyk, Neriton, Warszawa 2014, s. 277-309.

Gadacz Kornel, Przedwojewski Kornel, w zakonie Antonin, PSB, t. 28, Wrocław 19841985, s. 712-714.

Kęder Wojciech, Kryzys wokół sprawy dysydenckiej a sprawa suwerenności Rzeczypospolitej w latach 1764-1767 w świetle dokumentów papieskiego sekretariatu stanu, w: Rzeczpospolita wielu wyznań, red. Adam Kaźmierczyk i in., Księgarnia Akademicka, Kraków 2004, s. 365-374.

Kęder Wojciech, Od Viscontiego do Garampiego - nuncjatura warszawska w pierwszym okresie panowania króla Stanisława Augusta Poniatowskiego, w: Nuncjatura Apostolska $w$ Rzeczypospolitej, red. Teresa Chynczewska-Hennel, Katarzyna Wiszowata-Walczak, Benkowski Publishing \& Balloons, Uniwersytet w Białymstoku, Białystok 2012, s. 361-373. 
Kęder Wojciech, rec.: Magdalena Wrana, Angelo Maria Durini. Poeta i polityk w purpurze. Zarys działalności literackiej, kulturalnej i politycznej nuncjusza w Polsce, Kraków 2013, „Studia Sandomierskie” 21, 2014, s. 317-325.

Kęder Wojciech, Stolica Apostolska wobec Rzeczypospolitej w okresie konfederacji barskiej 1767-1773, Wydawnictwo Św. Krzyża, Opole 2006.

Konfederacja barska. Jej konteksty i tradycje, red. Anna Buchmann, Adam Danilczyk, DiG, Warszawa 2010.

Konopczyński Władysław, Konfederacja barska, t. 1-2, Volumen, Warszawa 1991.

Łubieńska Maria Cecylia, Sprawa dysydencka 1764-1766, G. Gebethner i Wolff, Warszawa-Kraków 1911.

Łukowski Jerzy Tadeusz, The Papacy, Poland, Russia and Religious Reform, 1764-8, ,Journal of Ecclesiastical History" 36, 1988, 1, s. 66-94.

Michalski Jerzy, Schyłek konfederacji barskiej, Ossolineum, Wrocław 1970.

Rostworowski Emanuel, Podoski Gabriel Jan h. Junosza, PSB, t. 27, Wrocław 1982-1983, s. $149-161$.

SIRIO, t. 67, Sankt Pietierburg 1889.

Systematisches Repertorium zur Buchzensur 1701-1813. Inquisition, wyd. Hubert Wolf, Ferdinand Schöningh, Paderborn 2009.

Vanysacker Dries, The Garampi Correspondence. A Chronological List of the Private Correspondence of Cardinal Giuseppe Garampi (1741-1792), Bibliotheek van de Faculteit Godgeleerdheid, Leuven 1997.

Vetera monumenta Poloniae et Lithuaniae gentiumque finitimarum historiam illustrantia, t. 4, cz. 2, wyd. Augustinus Theiner, Typis Vaticanis, Romae 1864.

Wrana Magdalena, Angelo Maria Durini. Poeta i polityk w purpurze. Zarys działalności literackiej, kulturalnej i politycznej nuncjusza w Polsce (1767-1772), Collegium Columbinum, Kraków 2013.

Zając Paweł, W objęciach Oświecenia. Prymasostwo i prymasi w czasach stanisławowskich, w: Dzieje prymasostwa polskiego, red. Łukasz Krucki, Gaudentinum, Gniezno 2017, s. 193-227.

Zielińska Zofia, Polska w okowach „systemu północnego”, 1763-1766, Arcana, Kraków 2012.

Biogram: prof. ucz. dr hab. Paweł Zając OMI - Zakład Historii Kościoła Wydziału Teologicznego Uniwersytetu im. Adama Mickiewicza w Poznaniu. Zainteresowania badawcze: historia nuncjatury warszawskiej w XVIII w.; kontakt: pawelarz@amu. edu.pl. 